\title{
Security, Religion, and Political Culture: A Defense of Weak Disestablishment
}

\author{
Joseph Prud'homme \\ Institute for Religion, Politics and Culture, Washington College, Chestertown, MD 21620, USA; \\ Jprudhomme2@washcoll.edu
}

Received: 7 January 2019; Accepted: 18 January 2019; Published: 29 January 2019

\begin{abstract}
Many, especially in the West, have long argued against state religious establishments on the ethical grounds of the rights of freedom of conscience and personal autonomy. Situating the question of religious establishment within the field of Religion and Security-an important and growing aspect of the Religious Studies discipline-allows for new interpretive possibilities. This paper explores the impact of religious disestablishment on the state's task of provisioning security from violent religious extremism. Could it be that states which have disestablished a formal or deeply embedded informal tie with religion are less able to provide security to their citizenry? I examine this question and develop the contention that religious disestablishment in the West has actually harmed the state's capacity to deal effectively with violent religious extremism. In turn, this finding requires us to reconsider the normative bases of strict church/state separation and provides one element within a range of arguments for what I label 'weak disestablishment.'
\end{abstract}

Keywords: religion; security; education; establishment; establishment clause; terrorism; violent religious extremism; religious freedom

Many political and legal theorists, especially in the West, have long argued against state religious establishments on the basis of personal freedom, religious liberty, and equal citizenship. What happens, however, when theorists situate religious establishments in the context of security measures undertaken to counter violent religious extremism? Could it be that states that have resisted calls to disestablish religion are better able to provide security to their citizenry?

To answer this question, we must first be clear on what precisely we mean by religious disestablishment. I differentiate three forms of disestablishment: weak, strong, and extreme versions. By the first, I mean the kind of separation of religion and the state that prevailed in the United States from the time of the ratification of the Constitution until the early 1960s. This model has three features: it permits a wide enjoyment of the free exercise of religion, yet it maintains a considerable degree of state support for the nation's historically preeminent religion even under the auspices of its non-establishment, and the degree of separation between church and state that it does effectuate is justified publicly on the basis of assisting the historically dominant religion to flourish, recognizing a special status to religious life in terms of the thriving of individuals and the state. By strong disestablishment, on the contrary, I mean the implementation of policies that not only legally recognize free exercise but seek to sever, as much as politically practicable, government support for the religion once dominant in society and supported by the state, and doing so is justified on a basis other than the flourishing of the country's traditional faith. Strong disestablishment goes beyond permitting free exercise of religion and generally seeks a strict separation of religion and government and speaks in the language of neutrality, but its nature permits the state occasionally to express some measure of support for historically marginalized religions, as its core animus is against the state's traditional support for one faith, and it shares with other social movements a strong endorsement of multiculturalism and 
(an often vague) sense of social justice, resulting in some forms of accommodation specially tailored to minority religions. Hence, strong disestablishment cannot be equated simply with strict church/state separation nor with laws guaranteeing freedom of belief and worship. Nor, however, can it be equated with extreme disestablishment, a movement to undermine religion in actively hostile ways through overt attacks, often undertaken against religion as such and not simply the historically preeminent faith, of the sort the Russian government and the Jacobins attempted during the nadir of Soviet and French revolutionary oppression.

So understood, strong disestablishmentarianism exists not as a legal abstraction but as a concrete political and legal movement, and it must be identified by looking beyond the superficial forms of government. I use a range of laws in the United States to illustrate just what is meant by disestablishmentarian public policies.

I next develop a set of security problems associated with the strong disestablishmentarian state, again with a focus on the United States. Four problems come to the surface. First, disestablishmentarian policy allows for the large-scale development of communities which can be, and have been, plausibly seen as containing a meaningful number of religious extremists. Second, disestablishmentarian policy has facilitated the implementation of security protocols that have been demonstrated to increase the exposure of states to violent religious extremism. Third, data based on patterns of religious violence across Europe suggest that strong disestablishment is connected with higher exposure to religious violence. Fourth, a number of experts have suggested-although the contention is hard to evaluate or quantify-that both the strict separationist aspect of disestablishmentarian policies and the occasional favoring of marginal religions actually serve to encourage radicalization among at least a non-negligible core of extremists or those susceptible to adopting extremist views.

These considerations, I contend, are sufficiently compelling-although the sprawling and evolving nature of the topics necessarily prohibits conclusive results-that the following question emerges: why are disestablishmentarian policies so relatively successful across the contemporary West? To be sure, serious policy arguments are to be found on all sides of these issues, and political debate roils over issues of immigration and terrorism policy in Western societies, including vigorous debates in the United States. Nevertheless, the problems listed above are so substantial that the question seems to be not why is there debate, but why does one aspect of the debate still face such strong opposition in legal rulings and policy forums? To develop an answer to this question I differentiate levels of strong disestablishment, distinguishing strong disestablishmentarian policy from strong disestablishmentarian political culture, a culture simultaneously expressing moderate to high levels of hostility to the once preeminent faith and high rates of endorsement of multicultural values. At least part of the answer to our question resides in the relationship between policy and political culture: state policies that strongly disestablish the once preeminent religion re-shape, to a considerable degree, that state's political culture. Certainly, the causal arrow between policy and culture is never unidirectional. However, as Marx and Engels said of capital, so we can say in a qualified sense of disestablishmentarian public policy: it creates a world after its own image. This feature in turn makes disestablishmentarian policies difficult successfully to question.

Lastly, I argue that these findings require us to reconsider the normative strength of strong disestablishment, and do so in two ways. First, the findings suggest that the United States should welcome a revisiting of the legal foundations of strong disestablishment, an option now made even more possible by the shift in the ideological center of the Supreme Court resulting from the confirmations of Justices Gorsuch and Kavanaugh.

Second, these findings supply arguments against political movements seeking to impose strong disestablishment on societies that either do not currently have it or have only recently come close to adopting it, such as calls for removing religion from its preferred place in Poland and the movement to secularize the Republic of Ireland. Drawing from the conceptual work on the nature of political and legal theory emphasized by Jonathan Wolf, I argue for a positive reconsideration of weak disestablishment against those who would seek to remove it. Properly designed, I argue, weak 
disestablishment can protect rights to free exercise of religion, and by grounding that right in a recognition of the special respect to be accorded religious life, necessarily also will recognize a panoply of other rights derived from religion's special position, ensuring in turn that the state promotes both human rights and human flourishing.

To develop these considerations I (1) review a paradigm instance of weak disestablishment by surveying the American system of church/state relations from the colonial period until the early 1960s. I then (2) outline the development of strong disestablishmentarianism in the United States from the 1960s until today. I next proceed (3) to survey a range of security challenges in the United States that have arisen in large measure as a result of this development. Subsequently (4), I ask the question why the problems identified have not sparked even more profound questioning of state policies, and then develop the position that political culture can meaningfully be seen as "downstream" from political and legal policy, making changes that could improve public security increasingly difficult to achieve. These conclusions, I argue, (5) must inform political and legal theory and argue for a positive reappraisal of weak disestablishment.

\section{The Classic American Model: Weak Disestablishment}

From 1789 until 1962, the United States legal system accorded religion considerable prestige, respect, and indirect cooperation. I shall outline the ways the United States over time broadened religious free exercise while still retaining substantial linkages between the state and the traditional religion of the majority of citizens. I shall also adumbrate how the separationism it did instantiate was publicly justified in a religion-affirming manner.

Religious liberty has long been called "the most cherished of American freedoms." ${ }^{1}$ In the words of legal scholar Robert George, "The United States was founded on the idea that religious liberty matters because religious belief matters in a uniquely life-giving and powerful way." ${ }^{2}$ True to its recognition of the power and importance of religion, the United States since its earliest founding has seen momentous efforts to ensure greater realization of the principle of religious freedom. The road has not always been straight and the task at times difficult, ${ }^{3}$ but the efforts have roots deeply woven in America's fabric and date as early as the mid-1600s. Rhode Island became a sanctuary of religious liberty as early as 1636 . Maryland was originally founded in 1634 on the very principle of expanded religious freedom, with the Maryland Toleration Act of 1649 formally authorizing a wide allowance for religious liberty. In turn, Pennsylvania and Delaware were founded by William Penn in 1701 and embedded religious liberty in their colonial laws from the very beginning. Although Maryland would lose its commitment to religious freedom in 1654 (a development tied to the mother country's revolutionary politics), it would regain its affirmation of religious freedom following the American Revolution. Moreover, at the same time in the 17th century that religious freedom waned in Maryland, it began to burgeon elsewhere in the colonies: North Carolina and South Carolina at this time both broadened their freedom of religious practice and did so on a basis explicitly incorporating John Locke's philosophy of religious toleration, while at the same time the state establishments in Georgia and New York allowed wider freedom of religious exercise. In 1776 Virginia, which had until then circumvented British administrative demands to broaden religious liberty, ${ }^{4}$ allowed for a wide freedom of religious practice, a measure

1 Pope Benedict XVI, quoted in “Our First, Most Cherished Liberty,” United States Conference of Catholic Bishops, available at http:/ / www.usccb.org/issues-and-action/religious-liberty/our-first-most-cherished-liberty.cfm.

2 (George et al. 2015).

3 A veritable cottage industry of work now critiques the founders on religious freedom and increasingly even the concept of religious liberty itself. See discussion of the work of Tisa Wenger discussed below, including (Wenger 2017). See also (Sehat 2016), a work that documents, with lamentation, the extensive cooperation between religion and the state until the 1960s. An important work, it would better be titled 'The Myth of American Secularism' or, in my terminology, 'The Myth of Strong Disestablishment.' On the plaintive character of the piece see the preface to the paperback version in which Sehat claims "we are now at a crossroads, with many people calling for a renewed place for religion in the public square. Count me among the many who hope such efforts do not succeed" (xii).

4 (Trigg 2014, pp. 8-11). 
championed by George Mason whose hand-crafted Article 16 of the Virginia Declaration of Rights mandated "Christian forbearance" for all who seek to worship God, whether Anglican or not. By 1777, all specific affiliation of states with Anglicanism came to an end-unsurprising given the historic trajectory toward greater religious freedom and the quite strong connection between Anglicanism and the British crown. ${ }^{5}$ However, in the immediate aftermath of the Revolution, religion and government became even more tightly interconnected in the New England states due to the strong support leaders of the New England established churches gave to the Revolutionary cause. ${ }^{6}$ Nevertheless, by the 1780s every state constitution or state-level declaration of rights included a provision for religious liberty, although variations existed from state to state. ${ }^{7}$

By 1834, religious freedom had made additional strides including the formal separation of the state and a particular denomination in all states in the country. True to the premise underlined by Robert George, the post-Revolutionary movement to expand even further the right of religious freedom was driven, as he, Michael McConnell, and others have documented, by a religious revival and the desire to ensure that the true importance of religion to human flourishing was properly appreciated. McConnell notes that to understand the developments leading to even greater religious freedom, "it is necessary to see them through the eyes of their proponents, most of whom were members of the most fervent and evangelical denominations in the nation"; for the "drive for religious freedom was part of this evangelistic movement" - one seeking to unleash the energies of religious communities-while acknowledging, with civic republicans, the positive value of religion for the public good. ${ }^{8}$

As such, religious freedom and respect for religion have historically been deeply interwoven in the United States. ${ }^{9}$ In fact, the federalism of the national Constitution expressly sought to avoid any measure that could undermine any state's solicitude toward religion, and the preservation of extensive state-level assistance to religion from the founding until the 1960s underscores this point. The United States originally secured constitutionalized support for state promotion of religious life through the Constitution's explicit separation of state and federal functions. ${ }^{10}$ Indeed, all ratifiers of the Constitution knew that six states in 1789 had official religious establishments, that is, the state accorded one denomination privileged status, often entailing direct financial support to this faith and no other and a range of symbolic and expressive privileges including prayer in and during governmental meetings and attestations of the importance of the endorsed faith. By not prohibiting these in Article 1, Section 10 of the United States Constitution, wherein are listed a range of other specific prohibitions on actions by the states, the Constitution tacitly yet clearly endorses the union of church and state, where it exists, at the state level. Indeed, the list of explicit denials of state-level power in Section 10 is substantial and addresses precisely areas where the founders detected grave problems with how states were then administering governmental matters, including (as the Constitution still does) such important areas as the currency, inter-state tariffs, and bankruptcy courts-all of which the Constitution specifically denied the states (and still does). Not so for state-level religious establishments. Given this federal structure, therefore, the original Constitution was in part a religion-enhancing document and, thus, to the philosophical question of whether government as such and religious promotion must be separated, the Constitution answered no. Indeed, as President Jefferson stated in his second inaugural address in 1805, "religious exercises are under the direction and discipline of state or church." At most, only the federal government had to have some measure of separationism,

5 Exceptions to colonial Anglican prelates' support for the British crown can be seen in colonial leaders such as Rev. William Smith, the founder of Washington College and the first provost of the University of Pennsylvania.

6 (McConnell 1990).

(Campbell 2012).

(McConnell 1990, p. 1437).

See also (Adams and Emmerich 1989, pp. 1621-22).

10 For more on the federal intent of the non-establishment clause see (Lietzau 1990). 
and even here the separation was limited. ${ }^{11}$ Additionally, we must note the conceptual issue, identified by constitutional historian James Hitchcock in his magisterial multi-volume account of the Supreme Court, that "by the very enactment of the free exercise clause, the framers in effect 'established' religion by giving it special recognition." 12 For the Constitution contains in the first eight provisions of the Bill of Rights enumerated rights and, in the Ninth Amendment, a large undefined reservoir of rights left "to the people." By enumerating the right to religious free exercise, the Constitution meant to establish 'religion' as a matter of especial importance and governmental solicitude, an element not to be defined and potentially redefined by "the people."

There is no reason therefore to ascribe a strict separationist political philosophy-a philosophy about what government as such should do in regard to religious life- to the original constitutional design. In fact, we can underscore this point by embracing the logic expressed by many in the contemporary legal left. Critics of the original Constitution, such as the highly influential civil rights activist Ralph Abernathy (who would assume the leadership of the Southern Christian Leadership Conference upon Martin Luther King Jr.'s assassination), have argued that the constitutional system was originally pro-slavery and anti-women, even though it allowed the states to decide matters pertaining to race and sex, since by the founders allowing the states to control as they saw fit slavery and voting rights they were, it is claimed, explicitly endorsing what some states chose in terms of restrictive laws. ${ }^{13}$ Abernathy therefore writes of the founders that they "created a Constitution that specifically prohibited blacks from enjoying their rights,"14 although the Constitution left race relations almost entirely to the states. By this same logic, therefore, the founders endorsed the state's connection with religion, which equally was left to the discretion of individual states.

What is more, although all the states which at the time of ratification had official religious establishments would disband their formal affiliations with a particular denomination, they would do so in ways that were not in line with strong disestablishmentarianism. First, the conceptual point developed by Hitchcock remains applicable at the state level: religious liberty was enumerated in state declarations of rights and constitutions and was not left simply as a lesser right potentially to be defined or redefined "by the people."

Moreover, Jonathan Zimmerman has documented the maintenance of government support for religion at the state level throughout the 19th and early 20th centuries. Zimmerman points to the preservation of such things as blue and blasphemy laws. Indeed, Zimmerman documents that after formal disestablishment took place at the state level, which occurred by the 1830s, "many states extended or even sharpened their anti-blasphemy laws." ${ }^{15}$ So, a disaffiliation with a particular sect or denomination did not entail disassociation of religion from the state whole cloth. Jonathan Boyd underscores this point with respect to public education. Boyd reports that a "close study of nine of the 19th century's most popular American history schoolbooks confirms that authors use providential

11 Chief Justice William Rehnquist summarizes some of the extensive federal support to aid religion as follows: “As the United States moved from the 18th into the 19th century, Congress appropriated time and again public moneys in support of sectarian Indian education carried on by religious organizations. Typical of these was Jefferson's treaty with the Kaskaskia Indians, which provided annual cash support for the Tribe's Roman Catholic priest and church. The treaty stated in part: 'And whereas, the greater part of said Tribe have been baptized and received into the Catholic church, to which they are much attached, the United States will give annually for seven years one hundred dollars towards the support of a priest of that religion ... [a]nd ... three hundred dollars, to assist the said Tribe in the erection of a church.' 7 Stat. 79 . From 1789 to 1823 the United States Congress had provided a trust endowment of up to 12,000 acres of land 'for the Society of the United Brethren, for propagating the Gospel among the Heathen.' See, e.g., ch. 46, 1 Stat. 490. The Act creating this endowment was renewed periodically and the renewals were signed into law by Washington, Adams, and Jefferson. Congressional grants for the aid of religion were not limited to Indians. In 1787 Congress provided land to the Ohio Company, including acreage for the support of religion. This grant was reauthorized in 1792. See 1 Stat. 257. In 1833 Congress authorized the State of Ohio to sell the land [472 U.S. 38, 104] set aside for religion and use the proceeds 'for the support of religion .... and for no other use or purpose whatsoever ... '" 4 Stat. 618-619. Wallace v. Jaffree (472 U.S. 38, at 104), J. Rehnquist, dissenting.

12 (Hitchcock 2004, p. 26).

13 See (West 2001).

14 (Abernathy 1990, p. 17).

15 (Zimmerman 2012). See also (Sehat 2016). 
language to teach students how to be good citizens of a Christian nation."16 Such state support for religion continued, and not only in terms of curricula in the state schools, but also through the active assistance by government of denominational schooling. After the failure in 1875 of a proposed federal constitutional amendment to impose separation of church and state on all state governments, 10 states still kept potential or actual state support for religious schools operative in their state laws. Within the four walls of the public schoolhouse itself, as late as 1948 over 2.1 million school children across the country were enrolled in voluntary religious instruction in public schools during official school hours, with the school day for many millions more opening with a prayer to the creator: the school day, therefore, could not have been called a religion-free-zone. In all as Carl Esbeck recounts, when the Supreme Court did come to impose strong disestablishment on the entire nation in the post-World War II period, a movement to which we now turn, it would do so on "unsuspecting state and local officials." 17

Indeed, it was only later in the 20th century that the United States would see the initial emergence of a stronger form of church/state separation. ${ }^{18}$ In the famous 1947 case of Everson v. Board of Education of Ewing Township the Court applied - for the first time in American history-the establishment clause of the First Amendment to the states (effectively imposing the failed constitutional amendment of 1875), a point it reinforced in its 1948 decision in McCollum v. Board of Education of Urbana-Champaign. ${ }^{19}$

However, two things are important to remember about these cases which reduce the degree to which they express strong disestablishment. First, it is often forgotten that the 1947 case was brought by a strong devotee of American church/state cooperation. Arch R. Everson, the plaintiff in the case, sought only to limit the state's support of one denomination of Christianity, not to eliminate state/church cooperation altogether. Everson himself allied with those who sought "to uphold the reading of the Bible in public schools." ${ }^{20} \mathrm{He}$ did not therefore seek a strong disestablishment. Second, the Supreme Court in both Everson and McCollum justified in substantial part its decisions by speaking of the measures as necessary to preserve the flourishing of the traditional faith of most Americans. For example, in both Everson and McCollum the Supreme Court asserts that "the First Amendment rests upon the premise that both religion and government can best work to achieve their lofty aims if each is left free from the other within its respective sphere." ${ }^{21}$ This sentiment-that separationism is a boon to religious vigor-is often forgotten in discussions of these foundational cases, but the claim finds expression across the majority, concurring and dissenting opinions in both rulings. Justice Wiley Rutledge, for example, asserts in McCollum that "our constitutional policy does not deny ... the value or the necessity for religious training, teaching or observance ... [for] it is not because religious teaching does not promote the public or the individual's welfare, but because neither [religious training nor the public or the individual's welfare] is furthered when the state promotes religious education, that the Constitution forbids it to do so."22 Disestablishmentarianism is signaled as a philosophy that helps religion to exert its ennobling effect. Indeed, in their concurrences in both cases, Black's judicial brethren anthem this conviction with an uncompromising civic piety: "we have staked the very existence of our country on the faith that complete separation between the state and religion is best for the state and best for religion." 23

\footnotetext{
Quoted in (Fea 2011, p. 9).

8 Some state-level movements moderating for example Sabbatarian legislation can be seen in various locales. See (Green 2010).

19 Everson v. Board of Education of Ewing Township, 330 U.S. 1 (1947); Illinois ex rel. McCollum v. Board of Education of School District No. 71, Champaign County 333 U.S. 203 (1948).

20 (Hamburger 2002, p. 455).

21 Emphasis added.

22 Emphasis added.

23 Emphasis added. This conviction is compatible with what we can call weak disestablishment's suspicions of a too close association of church and state that could imperil the church's freedom to witness to the faith as it sees best in light of changing social circumstances and its ability to organize, train, and discipline itself to best advance its mission. See
} 
Since Everson and McCollum were justified as being themselves expressions of support for religious vitality, the two cases could without surprise be followed by a reiteration of the traditional view of state/church cooperation. In 1952 the Supreme Court continued what we might in summary call the Classic Model of American Weak Disestablishment by upholding a measure whose clear purpose was to capitalize on the hours pupils were in school to advance the religious health of young people through facilitating optional out of class religious programming, and it would do so with the unsurprising assertion that American "institutions presuppose a Supreme Being" and, therefore, "when the state encourages religious instruction ... it follows the best of our traditions." 24

\section{The Rise of Strong Disestablishment in the United States}

We can now explore the emergence of a strong model of religious disestablishment. Since strong disestablishment involves a general adoption of strict church/state separationism conjoined with an opening to the use of the implements of the state to support in various ways historically marginal religions, we must attend not only to the emergence of strict separation but the expression of occasional state support for religions outside the historic national mainstream.

In the United States, the advocacy for a strong disassociation of church and state became much more heated in the 1960s, when a leading atheist activist demanded school-authorized prayer and devotional Bible reading be eliminated from the public school day. The activist, Madalyn Murray O'Hare, was well known and the case became a public sensation. The result reached by the Court-to eliminate entirely the option of locally accountable school boards to choose to start the school day with an optional and exceedingly vague endorsement of a theistic worldview-went against decades of established American tradition. Further, the decision in the cases that imposed this restriction, Engel v. Vitale in 1962 and its companion case Abington Township v. Schempp in $1963,{ }^{25}$ contained none of the pro-religious civic piety expressed in Everson and McCollum, no soaring rhetoric about making religion stronger. Instead, the decisions expressed what a fair observer should call anti-religious tropes and sentiments. As Black would state in a bitter dissent in Board of Education v. Allen, any aid by the state to religion "generates discord, disharmony, hatred and strife." 26 In the words of Supreme Court historian Hitchcock, the Court, in both its majority and dissenting opinions in its establishment clause cases in the 1960s, propounded the view that "history showed that any form of establishment tended to increase hatred and contempt" and to cause simple misery. ${ }^{27}$ Why a conjunction of the state and religious values and institutions would have this effect and not also the conjunction of the state and an innumerable number of other values, the Court never explains. Religion, therefore, now took on in the eyes of the Supreme Court a special toxicity—a proneness to division and tension-which the nearly unlimited range of other values and organizations the government daily supports is somehow naturally (miraculously?) immune from.

The Court reiterates this point in the way it proposes to police the poison of public religion. First, it espouses a solicitude needed against the worst of tyrannies: "trickling streams" of state support of religion, the Court declaims, "may all too soon become a raging torrent and, in the words of Madison, 'it is proper to take alarm at the first experiment on our liberties.'" Religion in public life,

Esbeck for a summary of this view (Esbeck 2007, p. 22). We must remember, however, that such autonomy from state intrusion in no way necessitates strict separationism: the pre-Everson American model, in fact, bears some similarities to arrangements found elsewhere in the Western world, particularly in Scotland (unsurprising given the deep Scottish roots across America). The Kirk in Scotland historically was both state-endorsed and proudly institutionally autonomous. American weak disestablishment goes further than the Scottish model in part by broadening state endorsement to a wider range of denominations and also by prescinding from many forms of direct tax support.

24 Zorach et al. v. Clauson et al., 343 U.S. 306 (1952). Emphasis added.

25 Steven I. Engel et al. v. William J. Vitale Jr. et al., 370 U.S. 421 (1962); School District of Abington Township, Pennsylvania v. Edward Schempp, 374 U.S. 203 (1963).

26 Board of Education of Central School District No. 1 v. Allen, 392 U.S. 236 (1968) For further discussion see (Campbell 2012, p. 321).

27 (Hitchcock 2004, p. 144). 
a nefarious experiment on our liberties, the Court proclaims. Public religion deserves therefore a vigilance necessitating a wholesale reworking of centuries-long rules of legal standing. In Flast $v$. Cohen, Black writing for the majority created a major expansion of taxpayer standing in establishment clause cases-creating what Esbeck calls "the legal fiction of taxpayer standing" in religion cases. ${ }^{28}$ In a range of situations merely paying taxes to a government that expresses religious values is sufficient to confer eligibility to sue, a right unavailable to taxpayers who object to just about any other expression of values by the state. No believer in economic growth and commercial development can, for example, sue a government for expressing its commitment to environmentalism. ${ }^{29}$ Why a specific surveillance of public religion? It seems very hard to reason to a conclusion other than that religion is poisonous, while environmentalism, or any other democratically affirmed value, is not.

Related to this, in the 1960s the Supreme Court first announced its clear commitment to neutrality between religion and irreligion-according religious vigor no particular attention. As Wesley Campbell has demonstrated, this move inverted the original understanding of religious freedom. ${ }^{30}$ For prevalent at the time of the Founding was the idea of religion as special: in the echoing words of Madison himself, religious freedom is "unalienable because the duties to God supersede worldly obligations." As such, "the Founders' understanding of free exercise as an unalienable right strongly suggests that this right was individually held and not understood to be a guarantee of governmental neutrality," as "the Free Exercise Clause guaranteed a natural, unalienable right." ${ }^{13}$ However, now, for the first time, the Court says it will suffer no "breach of neutrality,"32 indicating that state neutrality is the core of religious freedom, not the special status of religious worship and religious life. This point is amplified in the famous case of Lemon $v$. Kurtzman, where the Court prescribes a three-fold test to police public religion, one plank of which is the assurance that the "principal or primary effect [of a law is] one that neither advances nor inhibits religion." ${ }^{\prime 33}$ The logic of this new idea of neutrality entails state indifference to the health of the traditional religion of the citizenry-a remarkable position to be undertaken by an organ of the government in light of America's institutional and religious history.

Based on its novel notion of state neutrality, ${ }^{34}$ the Court would expand its sweep of newly illegal behaviors: it would ban prayer at optional graduation and extra-curricular events, ${ }^{35}$ ban the limitations of the range of religious symbols permissible on public property, ${ }^{36}$ and repudiate the affirmation of the proposition stated by the Supreme Court itself in Zorach v. Clauson-that the United States is a nation whose institutions presuppose a Supreme Being_-reducing the concept to an antique ceremonial parlor

28 Flast v. Cohen 392 U.S. 83 (1968), holding, in Esbeck's summary, "that even in the absence of actual 'injury in fact,' federal courts have standing to hear taxpayer claims brought under the Establishment Clause where it is alleged that congressional appropriations are being wrongly channeled to religion" (Esbeck 2007, p. 26).

29 See (Marshall 1991, pp. 358-59): “Outside the establishment area, the state's use of controversial symbols does not give rise to constitutional concern no matter how offensive those symbols might be."

30 (Campbell 2012).

31 (Campbell 2012, p. 316).

32 (Campbell 2012, p. 316).

33 Alton J. Lemon, et al. v. David H. Kurtzman, Superintendent of Public Instruction of Pennsylvania, 403 U.S. 602 (1971).

34 It might at first appear that the legal question of Mormon polygamy in the federally controlled Utah territory was an early federal expression of strict church/state separation. In the Supreme Court's decision in United States v. Reynolds, 98 U.S. 145 (1878), Justice Waite writes for the Court rejecting a religiously based right to polygamy and at one point quotes Jefferson's letter to the Danbury Baptists in which Jefferson states his belief that the Constitution erects a "wall of separation between church and state." Importantly, however, the Supreme Court operates in this case within its traditional mode of constitutional analysis that favors the historical religious sentiments of the American people, justifying the federal law banning polygamy in part on the fact that the practice is opposed to the traditions of Christian civilization, since, in the Court's words, "polygamy is almost exclusively the feature of the life of Asiatic and African people"-people at the time of the ruling who were overwhelmingly un-Christianized. Even after extensive missionary efforts in the 19th century-including by Black American leaders such as Lott Carey in the 1810s and 1820s-by 1900 it is estimated that there were only nine million Christians in Africa, still almost all in Egypt and Ethiopia (where the faith had deep roots) and the Southern tip of the continent (where European settlement had taken firm hold). See https://www.worldatlas. com/articles/the-origin-and-growth-of-christianity-in-the-african-continent.html. Although having deep roots in the Philippines, Christianity only in the 20th century has blossomed across Asia.

35 Robert E. Lee v. Daniel Weisman, 505 U.S. 577 (1992); Santa Fe Independent School District v. Doe, 530 U.S. 290 (2000).

36 County of Allegheny v. American Civil Liberties Union, 492 U.S. 573 (1989). 
piece, and not a statement the state sees as true. Most of these rulings ${ }^{37}$ the Court enacts over strenuous objections from four other justices, including not only conservatives Scalia, Rehnquist, and Thomas, but often also centrist JFK-appointee Byron White and other moderates. ${ }^{38}$

The call, in turn, has been taken up by an army of law professors intent on justifying the necessary corollary of state neutrality: that religion is of no especial solicitude for government. It deserves protection, to be sure, but only as a species of a much wider right to autonomy, since, based on neutrality, to justify religious freedom as a separate right would itself be to elevate religion in the eyes of the state. ${ }^{39}$ Indeed, Professor Wilfred Sullivan argues that a recognition of a separate right to religious free exercise would violate a more fundamental principle of a just government, the "higher" principle of equality. ${ }^{40}$

Strong legal disestablishment took root therefore mostly by agency of a narrow majority of the Supreme Court, but it has been promoted ever since by like-minded members of the intelligentsia and the political class. However, strong disestablishment, as we have noted, entails also a willingness by state actors to pursue a lower punctiliousness about supportive interactions between the state and religions outside the historical mainstream. That is, strong disestablishment allows for a lower protectiveness to be extended to the beliefs and practices of the traditionally preeminent religion at the same time that beliefs and practices of minority religions are more amply secured through state interventions. To see how this has occurred we must note that once religion through the logic of neutralism is not seen as a matter of special protective solicitude by the state-when, as Roger Trigg remarks, "any idea that religion, as such, is of special importance is absent" 41 - the law will undergo a radical alteration allowing religious life more easily to be subjected to other state priorities, especially concerns based on social justice for minority communities, whose religious practices can be subsumed under a broader category of cultural rights, and advanced energetically by and through the secular state. The logic underlying this development moves across at least three stages.

First, neutralism, as we have seen, is not supported by originalist jurisprudence, but instead is propelled precisely by a drive toward deeper conceptions of equality. The dynamic thrust of neutralism therefore is toward prioritizing equality as a social good.

Secondly, at the same time, neutralism also minimizes the forcefulness with which religious freedom can be a bulwark against popular agitation for this very quest for increasing equality which is a motor of neutralism itself. This can occur for at least four underlying reasons. First, it can happen because all rights no doubt can require mitigation in certain circumstances. ${ }^{42}$ In light of this fact, a state's focus on protecting neutralism can push that state to minimize its affording religion protections relative to other state functions-such as promoting equality in light of real or perceived disadvantages suffered by particular minority groups. As Trigg argues, the "protecting [of] religious people and [traditional] practices" in this context can be perceived as "involv[ing] discrimination in their favor" in public debate, ${ }^{43}$ since, it can be thought, 'of course we have to limit rights sometimes,' so a failure to do so here is just a privileging of religious liberty. Second, neutralism entails that all religions and all claims to conscience exist on the same plain, all meriting some level of presumptive state

37 Operating within the secularist paradigm, conservative justices in Lynch v. Donnelly, 465 U.S. 688 (1984) upheld Christmas displays on public property. See, however, Justice Brennan's dissent remarking how a justification based on a secular purpose for traditional religious practices drains such practices of "any significant religious content."

38 Even McCollum had been treated with alarm by moderate FDR appointee Stanley Reed. See his dissent in McCollum.

39 See for example Chris Eisgruber and Lawrence Sager, who endeavor to describe religion as a species of a vague right to autonomy undeserving of special status (Eisgruber and Sager 2007, pp. 5, 19, 52, 284). The late distinguished legal philosopher Ronald Dworkin put it thusly: we should not, "as a community, attach any special value to religion as a phenomenon" (Dworkin 2006, p. 61). See also the more acerbic book discussed below, by (Leiter 2012).

40 (Sullivan 2005, p. 157).

$41 \quad$ (Trigg 2013a, p. 102).

42 Reynolds v. United States, where the Supreme Court does not recognize the religious freedom rights of Mormon polygamists, is just such an example.

43 (Trigg 2013a, p. 33). 
protection. It offends neutralism therefore to see religious belief as a distinctive right rather than just one expression of a broader right to deeply held conscientious thinking about the world. However, as Trigg remarks, "when more systems of belief invoke protection, the less effective that protection can be. When everything is protected nothing can be." In turn, the new right imposed by neutralism, the right to 'freedom of religion and belief and conscience,' becomes a concept that can only be broadly and vaguely defined, and thus is easily subordinated to competing considerations of public policy, because, once again, all rights will require some measure of mitigation in some conceivable circumstances, and when a right that will inevitably entail some measure of mitigation is as ungainly and vast as this one, the mitigation of that right in reference to a more concretely definable right (say, the right to marry) can easily take preeminence. Third, as also argued by Trigg, there is a danger in broadening religion to include the catch-all category of conscience: this move can cause religion more readily to be associated with instances of conscientious belief that are utterly aesthetic or non-rational and subjective-a conscientious belief in 'living life as literature, ${ }^{\prime 44}$ or pursuing 'art for art's sake,' for example' - despite the fact that many religious believers see reason as deeply informing their personal faith. As Trigg argues, "with the inherently subjective associations of 'conscience,'" this move can rather easily allow the state to tell itself that the merely subjective must not "get in the way of the alleged objective status of rights and the dignity of humans" the state seeks to trumpet. ${ }^{45}$ Fourth, redefining pursuant to neutralism the right to religious freedom into 'the right of freedom of religion, or belief, or conscience' unleashes a tendency by the state to reshape religious liberty that can acquire a momentum that allows religion to be redefined even further. It can now become all the more possible for the state to redefine religion as merely a liturgical practice-as a mere 'freedom to worship.' However, as Trigg recounts, when "freedom to practice one's religion simply becomes freedom of worship, [it] is then all too easy for 'equality' to trump 'religion.'" 46

Thirdly, once the right to religious freedom as historically understood is substantially weakened, the state's drive to instantiate other objectives, such as to advance a deeper conception of equality, can advance without restraint. In turn, as Trigg argues, once religious freedom is subordinated to a state concern for equality, "minority religions can come to be favored." ${ }^{47}$ For when "the protection of minorities is a priority, the feelings of alienation and offence of a small number of people will more than balance the wishes of the majority for public recognition of their faith." 48 "The law," Trigg remarks, "can acquire its favorites," since "once disadvantage is identified as an important feature in the drive to equality, minorities are going to get more attention than majorities." In turn, "Christianity may find itself struggling at times to receive the same respect, and attention, as the minority religions of immigrant communities." ${ }^{\prime 4}$ This occurs not so much because one group's religious rights as such become formally preferred over another, but because equality for minorities is understood to be the equality for the minority's culture, and so cultural rights of minorities are now able to be furthered, including its religious practices, a development allowing the state to advance de facto the religious rights of minorities to the exclusion of the religious rights of the traditional majority.

To see that this has actually occurred in a modern constitutional democracy, it is first important to note how critical the exercise of a heightened caution is in surveying the relevant data, and how important it is be measured in our conclusions: the issue of potential government favoring of marginal religions has become highly politicized and accusations are easily found that do not merit serious examination (such as the malignant claim circulating in some communities in England that "the Government has Declared War on White English People" ${ }^{\prime 50}$ ). The emergence of government preference

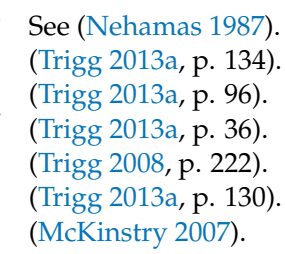


must not be exaggerated. Furthermore, the examples may not be numerous; what is relevant, however, is that there are any non-negligible number of public laws that clearly provide preferment to minority religions, even though the instances may be limited. Additionally, to see the issue of preference we must at times broaden our analysis to see the simultaneity of issues across the United States-the existence of measures in one region or at one level of government that are inconsistent with measures taken elsewhere. For we are not looking, as we point out below, only at inconsistencies within jurisdictions but also at movements in the wider American culture. Lastly, it is absolutely important to remember that although the focus in this work is on differential beneficial treatment of minority faiths, the state, in pursuit of its security objectives, will tend to expose those minority faiths in some ways associated with terrorism to differential treatment in the form of heightened security protocols not often imposed on members of the majority faith(s) — a point whose implications we shall also briefly survey. ${ }^{51}$

Although great caution and a critical eye are needed, measures that seem to express a 'multicultural' favoring of religions marginal in relation to American history can be seen to exist and to have taken three forms. First, there is the existence of preferential accommodations in public law. Second, there is what we might best term a preferential impulse in public policy toward differential minority protection, an impulse to extend accommodation to minority groups that are only as an afterthought and with hesitation extended to the majority faith community. Third, there are declarative preferences, that is, disproportionate emphases in the rhetoric of elected officials on behalf of members of a minority confession. Beneficial differential treatment to minority faiths in these three forms can to be seen across Western societies: in some respects, indeed, "the law [has] acquire[d] its favorites."

To see instances of the first form we can look initially to recent government actions in the state of Michigan and then turn to actions in Minnesota when viewed in comparison to recent legal provisions at the federal level, and we can conclude by referring to newly enacted municipal legislation in the state of Texas. To take one limited but clear example, in Hamtramck, Michigan the local police department has refused to allow Christians to distribute Bible-based literature on public property, but the city council at the same time has allowed local Muslim preachers to use the city's loudspeaker system to announce adhan, the daily calls to prayer. ${ }^{52}$ More broadly, in the neighboring state of Minnesota, the government has developed a program of Sharia-compliant home mortgages and business loans to allow Muslim recipients opposed to interest to accommodate their deeply held religious values, while they engage in activities outside their spiritual practices in their houses of worship, through home and business ownership..$^{53}$ Yet, at the federal level, at the same time the administration of Barack Obama developed an accommodation for the deeply held religious values of Christians opposed to abortifacients and artificial birth control that was limited so as to exclude its application to Christian life in wider society—such as the act of owning or operating a business—originally limiting the scope of religious accommodation only to spiritual practices in houses of worship. Moreover, in Austin, Texas, a city ordinance enacted in 2018 has mandated that all jobs in Austin be open to homosexuals and transgender individuals, with no exception for religious institutions including their hiring of officiating pastors or priests. ${ }^{54}$ This at once has placed a strong burden on the traditional faith of Texans but has also favored minority religions which have no explicit teaching against, or may even actively endorse, the behaviors/orientations in question. ${ }^{55}$

We can now refer to the more numerous category of what I have designated a preferential impulse in contemporary public policy. Here, it is not inapposite to remind ourselves of the fact that when

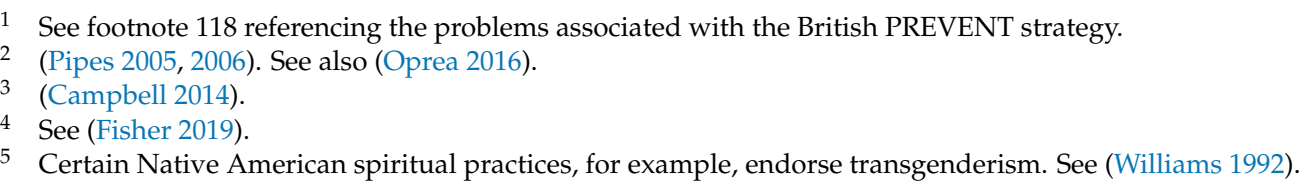


Native American religious practices involving hallucinogenic (and potentially addictive ${ }^{56}$ ) illegal substances were limited by a zealous application of federal anti-drug laws, a resounding majority in Congress rose up in a righteousness fit for that Sinaic God-seer who proclaimed "liberty throughout all the land"57: A Religious Freedom Restoration Act (RFRA) was passed unanimously in the House and by a 97 to 3 vote in the Senate. However, when similar laws have been introduced to protect religious practices of Christians (practices not implicating public safety-a standard state concern, as seen in the regulation of Indian hallucinogen usage), the stentorian sound of indignation has been turned against the traditional faith of the American people. Although some states have passed RFRA ordinances in reference to concerns over limitations of religious freedom involving in part restraints on Christians, other states have had much more limited success, such as Indiana, where political pressure based on a perceived favoring of traditional Christians resulted in its RFRA being substantially watered down. ${ }^{58}$

Additional evidence can be found once again in policies in Michigan, as well as in New York and San Diego, especially when both are viewed in comparison to broader national trends. In San Diego, in addition, recent controversy over anti-bullying polices also discloses an impulse toward preferential treatment of minority religions.

In Michigan, federal funds since 2014 are used to purchase halal-that is, religiously compliant-food in the Dearborn Heights public schools. A similar program has been enacted in San Diego. Reports indicate that halal meals cost the San Diego school district $20 \%$ to $30 \%$ more per meal than equivalent non-halal meals. Significant revenues therefore are involved: the Dearborn school district, for example, has entered into contracts totaling more than $\$ 228,000$ for halal meats. ${ }^{59}$ A major problem besets this policy, however: ensuring its consistency with the Supreme Court's ruling in Board of Education v. Allen. ${ }^{60}$ In that case, the Court held that having government funds assist religious students through publicly subsidized access to science textbooks was permissible but only if in doing so the government could not be viewed as aiding religion. The Court held that this untoward concern for religious vitality is avoided if the aid is available to all without regard to religious identity. The question relating to federal funding of halal meals, therefore, is whether the federal government equally funds special meals for all other individuals based on their membership in religious or ideological communities or organizations. Based on research conducted by The Middle East Forum, however, this long appeared to be doubtful. ${ }^{61}$ For many years there appeared to be no instance, for example, of the federal government subsidizing kosher food for Jewish students ${ }^{62}$ in heavily Jewish areas, although a non-negligible percentage of kosher-observant Jews (especially ones with special needs, which local Jewish schools are often unable to meet ${ }^{63}$ ) attend the public and not Orthodox schools. ${ }^{64}$ What is more, in one of the most diverse cities in the United States, New York City, from 2014 to 2018 City Council member Rafael L. Espinal Jr. of Brooklyn supported Resolution 54, which would have provided religiously compliant options in New York City public schools, but only for Muslim students. ${ }^{65}$

An impulse toward preferentialism in public education can also be seen in recent controversies surrounding anti-Islamophobia programming in public schools. The San Diego Unified School District

\footnotetext{
(National Institute on Drug Abuse 2016).

The Orthodox Christian tradition has long called Moses the 'Holy and Righteous Prophet and God-seer.' The quote, adorning the Liberty Bell in Philadelphia, is from Lv. 25:10.

58 See (Slodysko 2018).

59 (Markind 2015a).

392 U.S. 236 (1968).

(Markind 2015b).

(Jewish News Syndicate 2018).

(Benkof 2017).

(Markind 2015b).

65 (Marcus 2014). This preferential tendency has subsequently been mitigated In 2018 the City Council "inserted $\$ 1$ million in the city's nearly $\$ 25$ billion budget for a one-year pilot program that will provide kosher and halal lunches in two public and two private schools beginning in the fall" (https://jewishweek.timesofisrael.com/kosher-halal-school-meals-now-onthe-table/).
} 
in 2017 initially adopted a program that its supporters hailed as a novel, innovative, and "leading" program in the nation. ${ }^{66}$ As Stan Anjan, the executive director of Family and Community Engagement in the district stated of the newly adopted program, "It's more of a comprehensive program, not just a curriculum ... We're looking at it from a very integrated and holistic approach." ${ }^{\prime \prime 7}$ Pursuant to this "holistic" endeavor, social studies lessons were to include more information on prominent Muslims and their impact on history and other steps were to be undertaken to promote "a more positive image of Islam," Anjan recounted. To do so, the school district sought the assistance of religious advocacy organizations and "to engage in formal partnerships with the Council on American-Islamic Relations (CAIR)." What is more, when the program came to be further specified, it soon grew to one that would have educational modules to be attended only by Islamic students. ${ }^{68}$

As noted, the program was acknowledged by its advocates to be distinctive and unprecedented, with Anjan stating that the closest analogue to this comprehensive initiative was nothing in regard to religion: "the closest model for our Islamophobia work is our past work with the LGBTQIA community." ${ }^{69}$ No such program has been entertained that would address, for example, anti-Semitic bullying.

The San Diego school board justified this attention to one religion by reference to allegations of heighted anti-Islamic statements within its schools. Nevertheless, the tendance of this initiative bespeaks a thrust toward special preference. In fact, the decision immediately brought intense criticism from a wide range of parents and community groups, including Asian American activists through the San Diego Asian Americans for Equality organization, which became a lead plaintiff in a civil lawsuit alleging discrimination on the part of the district. ${ }^{70}$ As a result of the widespread protests of parents and community organizations, the district eventually "opted to revise the anti-bullying program to be more inclusive after facing public backlash for focusing on Islamophobia." ${ }^{\prime 71}$ Once again, the preferential impulse to minority religions is to be found both in actions that are differentially beneficial and in calls to actions which would be preferentially beneficial but which ultimately are mitigated.

As to the third form of minority preference-unbalanced rhetorical emphases by governmental officials-we can look at the statements of President Obama in his 25 September 2012 address to the General Assembly of the United Nations and his statements in his first overseas address, in Cairo on 4 June 2009. In the former, the president gave the sweeping remark "that the future cannot belong to those who slander the prophet of Islam." 72 Of course, geo-strategic considerations informed Obama's calculations, ${ }^{73}$ and no person of good will seeks to slander; the double standard, however, remains. However much we can agree that our future cannot countenance a mocking of individuals dear to religious communities, it would grate many to hear these words from the president whose administration endorsed sexologist Dan Savage, the 'sexpert' who said to conservative Christians that they just must "ignore all the bullshit in the Bible," and who mocked as "pansy-ass" high school students who objected to what he proudly called his "beating up on the Bible." "74 These are nothing

66 Hanif Mohebia, Executive Director of the San Diego office of the Council on American-Islamic Relations, quoted in (Warth 2017).

67 Quoted in (Warth 2017).

68 See https://www.fcdflegal.org/cases/citizens-v-sdusd/, reporting in reference to the initial proposal that "students of other faiths are excluded from this program."

69 Quoted in (Warth 2017).

70 Citizens for Quality Education, et al. v. San Diego Unified School District, et al.

71 (Bruno 2018). Despite this major concession, litigation has continued and, as of early January 2019, remains on-going. Viewed more broadly, one of the surprising elements in this case is the failure of the judicial system so far to see that anti-bias programs that closely align state education with religious organizations, such as CAIR, evince legitimate concerns under the Lemon Test, which prohibits "excessive entanglement" between the state and religious charities, an issue of "contradictory messag[ing]" identified by Liam Gearon (Gearon 2013, p. 6).

72 (The White House 2012).

73 As they have informed also much in the policy arena of immigration. See (Goodman 2017).

74 Quoted in (Daily Mail 2012). Savage later apologized on his blog (Savage 2012). However, a few days later he engaged in additional crude and maligning remarks. See (Brown 2012). 
if not negative stereotypes-slanders of the vilest sort. President Obama however declared in Cairo that, "I consider it part of my responsibility as president of the United States to fight against negative stereotypes of Islam wherever they appear." ${ }^{\prime \prime 5}$ Despite this, no condemnation of Savage was made by the Office of the President, and the partnership between Savage and the administration remained a hallmark of his administration's educational policy. ${ }^{76}$ What is more, in the address in Cairo, the president also stated that his administration would seek preferential arrangements for Muslim charities by revising anti-terrorism laws against giving material support to terrorism-associated organizations. ${ }^{77}$ Obama stated, "the rules on charitable giving have made it harder for Muslims" to give to charities and "fulfill their religious obligation."78 In response, he pledged to work with Islamic activists to change federal material assistance statutes. Obama therefore stated a desire to allow for special accommodations for donors to Muslim charities, since he proposed this without any reference to easing highly restrictive controls on donations to organizations in Columbia or Northern Ireland implemented since $1996 .{ }^{79}$

Again, many claims of differential religious treatment are either false or overstated, but, not all are.

\section{Strong Religious Disestablishment and Violent Religious Extremism: Risking Public Security}

What are the effects of strong disestablishment and its corollary, state neutrality toward the health or decline of the nation's traditional religion, on providing security from violent religious extremism? To begin to develop an answer we must first make a note on method. Our method in answering this question cannot be to seek anything close to apodictic conclusions; it can only be to highlight evidence suggestive of causal links between strong disestablishment and weakened security protocols. Moreover, the topic of religious terrorism is tremendously vast and ever-evolving, underscoring once more the need for a tempered approach to the conclusions plausibly to be drawn in assessing this question. We can provide only a short overview of a highly complex issue. What is more, as Douglas Murray, a generally harsh critic of European terrorism policies reminds us, it is a "fevered and fetid conspiracy theory" to see all security weaknesses as due to policy enactments and not to the inherent difficulties of the task, much less to see them as the results of policies in which multiculturalism seems to be a factor. ${ }^{80}$ Lastly, context remains king. Different regions of the world likely face different pressures in responding to religious extremism. ${ }^{81}$ Our focus again is only on the United States (with a brief excursion on British preventative policies).

75 (The White House 2009).

76 For the President's announcement of support see (Bond 2010; Meckler 2010). Obama was even videotaped the same day as the remarks about the "bullshit in the Bible" engaging in what appears to be fundraising with Dan Savage. See (Shapiro 2012).

77 (Preston 2010).

78 (The White House 2009).

79 And this despite significant documented threats of charities serving as fronts for violent religious organizations oversees, dating back to the 2007 trial of The Holy Land Foundation for Relief and Development. See Andrew C. McCarthy, the U.S. Attorney who prosecuted the terrorists responsible for the 1993 World Trade Center attack, in his work (McCarthy 2010, p. 252). In 2014 the Obama administration did change the admissions criteria for asylum seekers from the Middle East in a way that eased access for those having some material interaction with terrorist organizations such as ISIS and Al Qaeda, a policy I discuss in more detail below. Yet these changes occurred at the same time that data, reported by an editorial in Investor's Business Daily on 21 February 2014 indicated that "the State Department has rejected virtually all of the 20,000 asylum applications from Coptic Christians trying to escape Egypt since the toppling of its pro-American regime." Coptic Christians are rarely suspected of material interaction with Islamist extremists in Egypt and so their access was not eased by this policy change, leading the Investor's Business Daily editorial board (admittedly a long standing critic of the Obama Administration) to assert in this editorial that Obama's "new asylum decree favors Muslims over Christians." Editorial available online: https:/ / www.investors.com/politics/editorials/obama-immigration-reforms-seem-to-comewith-religious-test/. For restrictions on applicants suspected of material support for terrorism from Colombia and Northern Ireland, see (Chugani 2008, p. 617).

80 (Murray 2018).

81 For variability in the topic around the world see the report (Institute for Economics and Peace 2015). 
So qualified, I develop four arguments that link strong disestablishmentarian policy and government actions to risks to public security: a problematic conjunction of competing policies, a series of troubling governmental actions informed by neutralism and multiculturalism, empirical data suggesting a correlation between strong disestablishment and heighted exposure to violent religious extremism, and a speculative coda about strict separationism as an independent impetus to certain forms of religiously based extremism.

\section{(i) A Problematic Conjunction: Neutralism, Broadened Entry, and Imprecise Security Screening}

States whose policies are predicated on strong disestablishmentarianism tend to facilitate the creation of large communities of groups from which it has been demonstrated that extremism can and has emerged. This is due to a problematic conjunction of three policies created by the disestablishmentarian state: a minimizing of religion in public policy, the widening of immigration, and a reduction in and imprecision within the security protocols governing the vetting of immigration applications.

Before we see the conjunction and its problems, we must note that each element is partly informed by both aspects of strong disestablishment-its minimization of religion as such, and its tendency toward some degree of preference for minority religions. The former posture, with its commitment to the idea that religion is not special, can minimize religion in the state's calculations, causing the state to underestimate the role of religion in the life of individuals and communities, in turn causing the state to become blind to potential problems. ${ }^{82}$ As Douglas Murray argues, "in the 1980s or 1990s almost nobody predicted that the first decades of the twenty-first century ... would be riven by discussions about religion. The increasingly secular [world] had expected to be able to leave faith behind." 83 And so "no one who had opened up the borders ... to mass migration from the third world had even thought about it as a Muslim issue." ${ }^{84}$ And when they did, "politicians ... in general minimized the differences between Islam and other faiths. ${ }^{\prime 85}$ That the differences between Islam and the traditionally majority religion of the United States may not be vast, especially in comparison to a secularist worldview, we have no wish to question. What we do question is the idea that no problems at all inhere in immigrant communities of religious backgrounds different than the traditional religious core of the nation.

To the latter aspect of strong disestablishment—changes to immigration policy-these were informed to a considerable degree by a desire for greater diversity, although the specifically religious element of the diversity was not at first at the forefront. Neutralism, after all, is committed to being uninterested in the religious composition of the country.

Lastly, the reduction in security screenings in the immigration process can be shown to have originated in part with a desire to avoid offense to minority communities. The point here is not that broadened immigration access is problematic; it is the combination of it and reduced security

82 This despite the presence of indicators not only of direct violent terrorism but of religiously based objectives of some supporters of Islamic immigration overseas. The infamous documents found first in a raid in Lugano Switzerland in 1977 reference a meeting convened by Youssef Nada, director of a bank suspected by Swiss and U.S. officials of laundering to terrorist organizations. In the cache of documents found in the case was a document titled "The Project." In it is outlined a plan of "cultural invasion" to be effectuated by groups in the West affiliated with the Muslim Brotherhood. See (McCarthy 2010, pp. 59-58). See also (Besson 2005) outlining the extremists' goal of "cultural invasion." As one extremist Islamic scholar said, "by means of your democracy we shall invade you, by means of our religion we shall dominate you" (quoted in (Fallaci 2002, p. 98)). We should also note the documents found in the 2007 federal trial for terrorism-related money laundering in the United States, leading to convictions relating to the Holy Land Foundation charity, which make an even more elaborate articulation of the same agenda. Specifically, in a document prepared by Mohamed Akram, a known terrorist, he outlines a plan for a "grand jihad in eliminating and destroying Western civilization from within." See (McCarthy 2010, p. 58), quoting document in evidence at trial, titled "an Explanatory Memorandum."

84 (Murray 2017, p. 152).

85 (Murray 2017, p. 154). 
screening that gives cause for concern: it is when disestablishmentarian policy fuels at once increased immigration and decreased security that we experience a problematic conjunction.

First, to the issue of broadening entry, the 1965 Immigration and Nationality Act extended immigration access geographically and also allowed for family-based immigration policies. Although tied to earlier changes, and justified in part by reference to Cold War strategic considerations, this act nevertheless has been seen by most historians as a "milestone in the telos of American liberal pluralism" 86 and an expression of a de-emphasis on the traditional faith groups of the majority of Americans at the time, a point mentioned repeatedly by the Act's opponents, such as Senator Sam Ervin of North Carolina and Representative Ovie Fisher of Texas. The 1965 Act has since been augmented with the Refugee Act of 1980. The Act was intended to broaden asylum and refugee claims beyond applicants from communist countries (the overwhelming majority of such applicants were then from the Soviet Union, Eastern Europe, or the recently fallen Republic of Vietnam). In turn, the Refugee Act has subsequently permitted large numbers of admissions, especially from Somali and Iraqi. Added to this is the Diversity Lottery program -also known as the "green card lottery"-a program enacted in 1990, and which has allowed to date over 1,000,000 entrants. Although initially proposed with at least some intention of aiding mostly Irish immigrants fleeing an escalation in the Troubles and an economic downturn in the 1980s, during its legislative drafting the bill soon became framed, in the words of immigration historian Carly Goodman, "as an issue of diversity, borrowing the word from a 1981 report by the Select Commission on Immigration and Refugee Policy that identified cultural diversity as an important goal. The choice of words reflected the popularity of diversity as a cultural value $^{\prime \prime 87}$ in the eyes of government officials. The program continues to be justified primarily on the basis of diversifying the United States. ${ }^{88}$ Lastly, we can also add such policies as the State Department's Resettlement Programs, such as the "Africa Priority Three Program," conferring special attention on African nations including Somalia. ${ }^{89}$

As to reduced immigration screening, during the decades when immigration access was loosened, security requirements for entry have tended to decline in rigor, despite variability, especially since 9/11. In fact, the Diversity Lottery program has progressively eased entry security requirements, requiring now only a standard criminal record review and a statement that the applicant is not at the time of application in a country on the United States' terrorism watch list, a statement that experts have shown is rarely able to be adequately verified. As Janice Kephart, Special Counsel to the Senate and a National Security Fellow at the Center for Immigration Studies, testified before Congress in 2011, "Neither qualifications nor identity can be properly vetted. The program does not know, really, who these applicants are or their true purpose in coming," a point also made by the Gatestone Institute's review of the Diversity Lottery program, which finds that "in most of the countries eligible for a diversity visa, neither education nor work experience can be verified, let alone identity." echoed by Senators Tom Cotton and David Perdue, who note that congressional hearings disclose that the Diversity Lottery "is plagued with fraud." ${ }^{\prime 1}$ In all, it seem likely that Kephart's summary rings at least partially true: "The whole process makes a mockery of attempts to apply even the most minimal of requirements." 92

This imprecision in the immigration vetting process has been deepened by recent policies requiring immigration officials not to look more exactingly into the background of applicants. Under the Obama administration, as disclosed by John Cohen, a former acting Under-secretary for Intelligence and Analysis with the Department of Homeland Security, "agents working for U.S. Citizenship and

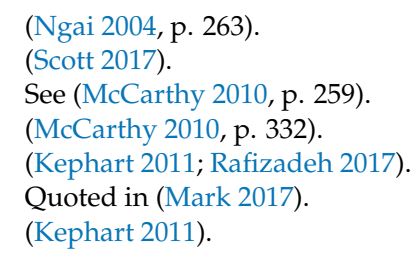


Immigration Services (USCIS) and U.S. Immigration and Customs Enforcement (ICE) were not allowed to use or review social media as part of the screening process" of all foreign citizens applying for U.S. visas. ${ }^{93}$ In fact, the policy was enacted in secret (so as to have immigrants retain a fear that their social media might be investigated). After concerns were expressed by veteran immigration officials, Homeland Security Secretary Jeh Johnson refused in early 2014 to change the secret program, fearing a civil liberties backlash and "bad public relations" for the administration. ${ }^{94}$ However, in the fall of 2014, the Department began three pilot programs to include social media in vetting, but officials at the time said that it still did not become a widespread policy. ${ }^{95}$ As of 2016, the immigration agency "conducts vetting of publicly available social media information on a very limited basis for certain applications identified for additional screening, or in cases where criminal activity is suspected." 96

Added to this was a policy enacted during the same time period that reduced denials of entry based on charitable giving to organizations the government identifies as linked to terrorist activity. The Obama administration in 2014 "ordered the State Department and Homeland Security to ignore a post-9/11 law barring entry to those giving political or charitable aid to Hamas and other known terrorist groups." ${ }^{\prime 97}$ The policy change, which has since been revoked, allowed entry to individuals whose contributions to and interactions with organizations associated with terrorism were deemed by officials to have been minimal, including, in the words of the new policy, "individuals who have provided support under significant pressure that does not quite rise to the level of duress (for which there are already exemptions in place) ${ }^{\prime \prime 98}$ — largely subjective, inexact determination.

The question must now be asked whether the conjunction of increased access to the country and reduced security protocols can really be considered problematic. Is the issue one of a conceptual possibility for problems or of demonstrated security failures arising for the policy conjunction? In fact, the combination of a larger pool with at times a low level of background review has been shown to be a factor in terrorism attacks in the United States. I shall survey briefly two documented instances followed by a general review of previous failures.

First, the deadliest terrorist attack in the United States since 9/11 occurred in San Bernardino, California when on 2 December 2015 Tafsheen Malik killed 14 people in a community center. Malik had been admitted to the U.S via a fiancé visa program. His wife had extensive social media background that might have been detectable by federal immigration officials. The State Department itself was clear on the point, saying in an official statement by spokesman John Kirby that "obviously, things went wrong in the visa background check for one of the San Bernardino shooters. Obviously, I think it's safe to say there's going to be lessons learned here." ${ }^{\prime 99}$ In addition, former Department of Homeland Security Under-secretary Cohen said he and others pressed hard for a policy change in 2014 that would have allowed a review of publicly-posted social media messages since, in his words, "terror group followers increasingly use ... Twitter and Facebook to show their allegiance to a variety of jihadist groups." Cohen said a number of officials from United States Citizenship and Immigration Services and U.S. Immigration and Customs Enforcement had "pressed for a change in policy."100

Second, Dzhokhar Tsarnaev and Tamerlan Tsarnaev-the so-called Boston Marathon bombers-killed three people and injured several hundred others, including 16 who lost limbs, on 15 April 2013 at the finish line of the Boston Marathon, and thereafter killed MIT police officer Sean Collier. Both originally entered on a Diversity Lottery visa. In addition, Tamerlan's entry was highly problematic. He had been identified as a person of concern well before the Boston attack. Russia's

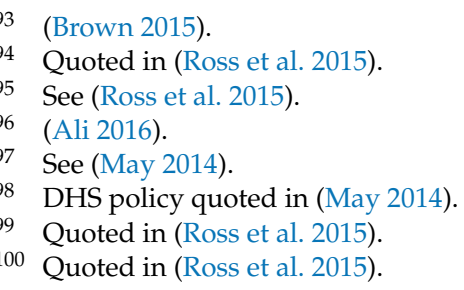


Federal Security Service told the FBI that Tsarnaev was a follower of Islamic extremism and that he was preparing to leave the United States to travel to the Russian region to join unspecified underground groups, ${ }^{101}$ which U.S. House of Representatives Homeland Security Chairman Michael McCaul later said was a terrorist training camp at which Tamerlan became further radicalized. ${ }^{102}$ In 2011, Tamerlan was interviewed by the FBI and his 2012 application for citizenship was flagged for concern and not processed. He at one point was placed, and remained at the time of the Boston bombing on, the FBI's "Terrorist Identities Datamart Environment" list of potential terrorists. ${ }^{103}$

Several other examples demonstrate the problems in the vetting of the Diversity Lottery applicants. Of course, it bears repeating that no vetting process can be perfect; despite this fact, a maxim of Christian scripture holds true: you can judge by the fruits. Sayfullo Saipov, the so-called Bike Path Killer, who drove a rental truck on 31 October 2017 into a large crowd of pedestrians, killing eight and injuring a dozen others, came to the United States under the Diversity Lottery program in 2010. In addition, Hesham Mohamed Hadayet, who killed two people at the Los Angeles International Airport on 4 July 2002 was allowed family entry due to his wife's receiving a Diversity Lottery visa in 1997. Lastly, the Michigan sleeper cell member Karim Koubriti, who was convicted in the summer of 2004 on terrorism-related charges, was a Diversity Lottery winner from Morocco. ${ }^{104}$ In light of these facts, we can appreciate the sentiments of Janice Kephart who concludes her congressional testimony by stating: “The Diversity Lottery program is a national security vulnerability, and has been used by terrorists and organized criminals to not only enter the United States, but to bring others in as well." Hence it seems compelling to say, as does immigration scholar Majid Rafizadel, that "instead of worrying about political correctness," the U.S. immigration system should stop a program many see as "their opportunity to take advantage of a hole in our immigration security."105

In all, with respect to immigration vetting not only through the Diversity Lottery program but in all areas of current policy, a report by Senator Sessions documents that " $65 \%$ of all publicly available terrorism convictions in the U.S. were of individuals who were foreign born and who had immigrated to the country." In turn, the report concludes that the data "make clear that the United States lacks the ability to properly screen individuals prior to their arrival to the United States." 106

\section{(ii) Problematic Governmental Practices}

We can now turn attention to a range of problematic government practices beyond immigration policy that are documented to have contributed to attacks by violent religious extremists. In addition to the problematic conjunction surrounding immigration policy, there are demonstrable cases of individual actions that have unwittingly allowed terrorism to succeed that are attributable to a government agents' neutralist and multiculturalist mindset. Again, we must remain extremely cautious with sources; nevertheless, the following examples have been widely documented.

First, the United States government has at times adopted a practice of not adequately checking the background of applicants to sensitive positions. The Clinton administration, for example, designated as its good will ambassador to the Muslim world Abdurrahman Alamoudi. In September 2003, Alamoudi was arrested in London, extradited, indicted, and put on trial, during which he pled guilty to funneling millions of dollars to Al Qaeda, and he was sentenced to 24 years in prison. ${ }^{107}$

A second example comes from after 11 September. That attack showcased the grave need for the security services of the United States to increase the number of Arabic speaking analysts and agents.

101 (Goldman and Sullivan 2013).

102 (CNN Newos 2013).

103 (Hosenball 2013).

104 (Goodlatte 2017; Kephart 2011).

105 (Rafizadeh 2017).

106 For a transcript of the report, released on 22 June 2016 see (Bedard 2016).

107 (Department of Justice Memorandum 2004). 
In fact, at one point the FBI had only six Arabic speakers, so the need was (and still remains) dire. ${ }^{108}$ However, the drive to meet a critical need was served through a practice of reduced background checks on future and current employees. This practice held tragic consequences in 2009. ${ }^{109}$ The so-called Fort Hood terrorist shooting on 5 November 2009 by Islamic extremist Nidal Hasan killed 13 people and wounded 32. An FBI report issued by a former FBI director showed that Hasan had been in frequent email contact with a suspected enabler of terrorism, Anwar al-Awaki (who was later killed in a drone strike in Yemen). ${ }^{110}$ As former federal prosecutor Andrew McCarthy relates, "The FBI was well aware that a Muslim psychiatrist responsible for treating our soldiers was in fairly constant contact with a suspected terrorist imam." ${ }^{111}$ In fact, Hasan was known to be expressing extreme Islamist ideas. He had even given a presentation providing the Koranic justifications for violent jihad and even stated approval of the logic of terrorist attacks, ${ }^{112}$ which the service was puzzled by, but thought was possibly a part of a research project. ${ }^{113}$ However, the FBI did not tell the military of Hasan's emails to al-Awaki. Nor did the Army or the FBI initiate its own investigations. Why? As McCarthy relates, "it didn't seem worth enduring the Flying Imams treatment," ${ }^{114}$ referring to a 20 November 2006 incident, widely publicized at the time, during which six imams were asked to be removed from a flight at the Minneapolis-St. Paul International Airport based on several reports by passengers of suspicious behavior. The imams protested their removal, alleging they were singled out on the basis of their religion, and were removed by police and detained for questioning for over five hours by local and federal authorities. The issue became a pubic sensation, and a lawsuit was filed and was later settled for an undisclosed amount. In McCarthy's judgment, the shadow of this incident skewed the judgment of Army officials regarding the earlier unexpected behavior of Hasan and the FBI's decision not to inform the Army of the information it had acquired about his connections with a suspected terrorist. McCarthy's judgment that "political correctness" informed the decision not to investigate Hasan before the incident is underscored in the formal review of the attack commissioned by the FBI and chaired by former FBI Director William Webster as well as in briefings supplied to congress, according to Representative Michael McCaul, the Chairman of the House Committee on Homeland Security. ${ }^{115}$

A third example is seen in the very mother-load of religious extremism, the attacks on 11 September. Before the attack, the Phoenix office of the FBI drafted a memo based on extensive surveillance and investigative work concluding that a general review of flying schools in the United States enrolled in by Arab nationals was necessary, as it seemed that a development was emerging in which terrorists would learn to fly as a means of perpetrating attacks. The report, sent to FBI headquarters, however, was not sent to the field. Investigative journalists David Johnston and Don Van Natta Jr. of The New York Times report that FBI officials at headquarters who described the decision pointed to this reason: "the worry that such an effort might be criticized in Congress as racial profiling."

108 (NBC News 2006).

109 For accounts alleging deep penetration by extremists into the U.S. military and government, see Hoover Institution media fellow (Sperry 2008).

110 See (Webster 2012).

111 (McCarthy 2010, pp. 360-61).

112 Hasan stated in his report, "I would assume that a suicide bomber whose aim is to kill enemy soldiers or their helpers but also kills innocents in the process is acceptable." Quoted in (Blake 2013).

113 (McCarthy 2010, p. 361).

114 (McCarthy 2010, p. 362)

115 (Associated Press 2012). See the redacted (Webster 2012, pp. 80-85). For a scathing critique of the FBI in this case from a left-leaning source, see (Blake 2013). 
Such a concern ${ }^{116}$ produced a "paralytic fear of risk-taking." 117 The Phoenix memo points to the failure of agencies to pursue valuable leads due to fears associated with singly out a particular religion. ${ }^{118}$

\section{(iii) Empirical Considerations}

Another line of argument connecting strong disestablishment and increased exposure to violent religious extremism can be found in correlational data suggesting a linkage between strong disestablishment and religion-based terrorism. In the Western world, religious terrorism is lower in states with weak disestablishments and higher in states with strong disestablishment. As is well known, the second deadliest terror attack in Europe, killing 137 people and wounding over 300 others, occurred on 13 November 2015 in strongly secularist and disestablishmentarian France. According to the 2017 Global Terrorism Index, published by the Institute for Economics and Peace almost two years to the day following the Paris attack, a strong correlation exists between strict separationism and rates of terrorist violence. The number of attacks in descending order across Europe is counted, as follows:

$$
\begin{array}{ll}
\text { 1. } & \text { France-5964 } \\
\text { 2. } & \text { U.K.-5102 } \\
\text { 3. } & \text { Germany-4917 } \\
\text { 4. } & \text { Belgium-4656 }{ }^{119}
\end{array}
$$

The countries in Europe with the least number include Poland and Slovakia, the latter in fact having no terrorist attacks. ${ }^{120}$ This data represents a correlation between strong disestablishment and terrorism, since France, Germany, Belgium, and the United Kingdom have each adopted, to varying extents, the core components of strong disestablishment: state neutrality toward religion accompanied by a multiculturalist attitude toward foreign immigration, especially strong in the 1980s and 1990s. ${ }^{121}$

116 A problem echoed in civilian life. The neighbors of the San Bernardino terrorists reportedly suspected the couple were dangerous but feared telling authorities lest they be thought to profile Muslims, at least according to a statement to local television reporters. See (Fox Neww 2015).

117 (Johnston and van Natta 2002).

118 A similar problem may beset the PREVENT program in the United Kingdom. As the BBC reported, two of the associates of the 22 May 2017 Manchester arena bombing perpetrated by Salman Abedi reported him to an anti-terrorism hotline, but PREVENT officials never were made aware of this, according to reporting by the BBC (https:/ /www.bbc.com/news/ukengland-manchester-45005029), a fact likely due to the agency's being overwhelmed partly due to inadequate resourcing. See https:/ / www.telegraph.co.uk/news/2017/05/24/governments-anti-terror-prevent-programme-must-strengthened/. In fact, David Anderson, the former independent reviewer of terror legislation, reports to the BBC that PREVENT receives only $1 \%$ of the overall $£ 3 b n$ counter-terrorismbudget (https:/ / www.bbc.com/news/election-2017-40151991), a fact itself a possible function of a concern over singly Islamic communities out. In addition, the PREVENT strategy has, it is alleged, suffered also from a watering down of its programming focus. To avoid criticism from minority groups, Ian Acheson, a former counter-terrorism official and Director of National Security Programs at Samson Hall, has argued that PREVENT has now started to allow wide latitude to suspected extremists, a result of what Acheson calls "institutional timidity" (Acheson 2018).

119 The Telegraph summarizes the data at https://www.telegraph.co.uk/travel/maps-and-graphics/Mapped-Terror-threataround-the-world/.

120 (Murray 2017, p. 199).

121 See (Murray 2017), for a discussion of European immigration in the 1980s and 1990s. Belgium has gone so far in pursuit of neutralism to grant public funding to Atheist organizations, with the Conseil Central Laïque ("Central Secular Council") first receiving public funding in 2001 and receiving public funds ever since. Although England has a formal linkage uniting throne and altar, that union is about as antiquated as the throne to which the Anglican Church is wed. As Trigg remarks, "'Establishment' is no longer a vehicle for Anglican privilege, as it perhaps once was" (Trigg 2013b). The Anglican Church receives no financial preferment. Its 26 reserved seats in the House of Lords have been offset in part by the creation of so-called People's Peers in 2010 as by the growing percentage of non-Christian peers in the approximately 800 member chamber. In terms of religion and the public schools, the Education Act of 1944 reiterated the Christian character of public religious education: the Act mandated that all state-supported secondary schools have religious instruction, with a focus on students mastering the fundamentals of Christianity understood non-denominationally, as well as mandating state-supported schools provide frequent collective acts of non-denominational Christian worship. Starting, however, at least in 1971 with the Schools' Council Working Paper No. 36, an agenda in religious education began to take shape replacing Christian education with the study of world religions. Aided in 1985 by an official British Enquiry into the Education of Children from Ethnic Minority Groups chaired by Lord Swann, this movement culminated in the 1988 Education Reform Act, one of the most significant education acts in the 20th century. This act mandated that all religious education in 
On the other hand, the Polish Constitution has a strong sense of governmental connection with religion and avoids strict separation. As Graham Walker has noted, Poland has seen it "impossible, despite the urgings of visiting American legal scholars, to adopt a postcommunist constitutional settlement in the mold of American religious neutralism."122 In fact, its constitution specifically eschews this by noting the "amicable cooperation of church and state for the common good."123 Slovakia also eschews strong disestablishment, with state support for religion embedded in governmental practice. ${ }^{124}$

This data of course is only correlational, but, it is suggestive. No doubt terrorists often seek to strike havoc in the most economically consequential and dynamic countries, and the relatively diminished status economically on the global stage of Poland, and all the more so of Slovakia, accounts for some of this correlation, but we should not read too much into relative geo-political positions. Islamic terrorism in particular has shown a tendency to engage in symbolic targeting, so an attack on the nation that supplied King Jan III Sobieski's 11 September 1683 defense of Vienna should not be ruled out. Plus, we know that ISIS has expressed a desire to attack churches when most crowded and full of celebrants—and the pews are quite full in the land of St. John Paul the Great. ${ }^{125}$

\section{(iv) A Speculative Coda: Strong Disestablishment Itself Might Encourage Islamic Extremism}

At the same time, some analysts have argued that state neutrality toward its citizens' traditional religion is seen by extremists as an expression of weakness and decadence on the part of Western nations, emboldening further terrorist activity. ${ }^{126}$ As Guido Steinberg argues in his work on German terrorism, Islamists are driven by ideology and less so by economic issues such as unemployment. ${ }^{127}$ Additionally, this ideology embodies to a very large degree the thought of the individual whom analyst Paul Berman has called "the philosopher of Islamic Terrorism": Sayyid Qutb. The root of the tension between the Muslim world, as Qutb defines it, and the West resides in Qutb's mind with the mistakes of "the early Christians ... whose legacy" created a "hideous schizophrenia": the rigid separation of the secular and the sacred. As Berman recounts, "The truly dangerous element in American life, in [Qutb's] estimation, was not capitalism or foreign policy or racism or the unfortunate cult of women's independence. The truly dangerous element lay in America's separation of church and state- the modern political legacy of Christianity's ancient division between the sacred and the secular." As the separationist principle became increasingly enshrined in the life of the West, Qutb saw "his deepest quarrel [to be] not with America's failure to uphold its principles. His quarrel was with the principles." 128 This overweening concern was rooted no doubt in his recognition that a consistently strict separation of church and state would preclude the establishment of the true path to human peace, in Qutb's eyes: Sharia. His concern with separationism, however, flowed also from the way he saw disestablishment minimizing the transcendent and the divine in all their expressions, which in his

state-supported schools "take account of the teaching and practices of the other principal religions represented in Great Britain," which was seized upon to further advance a multicultural educational perspective. This trend was amplified in 2004 when The National Non-Statutory Framework for Religious Education was produced, its broad aims reiterated in Religious Education Guidance in English Schools. See (The Qualifications and Curriculum Authority 2010). In this new trajectory, as Liam Gearon and Joseph Prud'homme point out, school materials for teaching world religions-primarily Buddhism, Christianity, Hinduism, Islam, Judaism and Sikhism—became preeminent, with religious education now "mak[ing] marginal references to the Bible" (Gearon and Prud'homme 2018, p. 125). At the same time, collective acts of religious devotion are observed in the breach. More generally, the Human Rights Act of 1998 officially demands state neutrality toward all religions, although its implications appear not yet to have been fully realized. Nevertheless, as Anthony Bradney asserts, "the Human Rights Act of 1998 has radically changed the legal landscape" (Bradney 2010, p. 740). One way it has done so is by stimulating the removal by statute of the historic protections for the Anglican Church in common law against blasphemy, all of which were removed by the 2008 Criminal Justice and Immigration Act, sect 98, although such a symbolically important move was only five years earlier opposed strongly by the House of Lords. See (Trigg 2008, p. 24).

122 (Walker 2000, p. 119).

123 (Walker 2000, p. 120).

124 (Trigg 2008, p. 16).

125 See (Morrissey 2018).

126 See, for example, (Federer 2008).

127 (Steinberg 2013).

128 (Berman 2003). 
mind led only to "disbelief." Additionally, disbelief for Qutb was no small matter. He writes that the "crime of disbelief" is to be "reckoned as equal in punishment" to "the crime of murder."129 Strict separationism as a legal system therefore deserves the same punishment meted to the murders of the children of God: destruction. Given Sayyid Qutb's influence, strong disestablishment itself might only embolden the followers of Jihadi extremism.

Would, however, the degree to which there is some measure of minority religious preference mitigate these concerns? Some theorists have said, on the contrary, that such concessions in fact only embolden extremists. Andrew McCarthy, for one, states rather boldly the conviction that "Islamists are taking the measure of the West and are finding it to be a shallow and self-loathing husk."130 This may well be overstated. However, it bears remembering that millions of U.S. dollars were spent assisting extremist Muslims in Afghanistan throughout the 1980s, yet an Islamist attack occurred against the World Trade Center only four years following the Soviet army's withdrawal from Afghanistan. Many millions more were spent by the United States defending Muslims in Bosnia in 1995, yet extremists only three years later attacked the United States' embassies in Kenya and Tanzania. And U.S. troops were removed from Saudi Arabia-a key demand of Osama bin Laden-in 2003, yet extremist attacks continued. To be sure, myriads of reasons inform terrorist activities. However, extending a costly solicitude to co-religionists seems not to have placated jihadi extremists, and might only have emboldened them further.

\section{Why the Strength of Security-Threatening Policies: Strong Disestablishment Creates a World after Its Own Image}

Despite having a tone at times overly polemical, former senior federal prosecutor Andrew McCarthy makes a suggestive point in a 2016 essay: in regard to security threats facing Western nations, he writes, "so obvious is this" all. ${ }^{131}$ This recognition gives rise to the question of why in representative democracies the policies that have been shown to jeopardize security remain relatively privileged. The question is not, why are these policies advanced and defended with passion? Nor is the point here that positions such as Peter Beinart's and developed in works such as The Good Fight: Why Liberals_and Only Liberals_Can Win the War on Terror ${ }^{132}$ must be seen as false. The question, instead, is why are such positions so disproportionately adhered to in the face of considerable counterarguments, and why are these very counterarguments often vilified as beyond the political pale?

To be sure, there are wide ranging debates in Europe and the United States precisely on the topics of immigration, security, and terrorism. No doubt the rise of political parties outside the post-War political establishment in Europe, as well as the election of Donald Trump in the United States, further reflect in part the power of concerns of this nature. However in Europe, the Swedish Democrats underperformed; Geert Wilders lost; and Angela Merkel remains (with her handpicked successor, Annegret Kramp-Karrenbauer, chairing her party). In the United States, Obama won two terms. Additionally, President Trump has historically low approval ratings, and his measures have met with serious opposition by a wide number in the federal government and across layers of American governance. In turn, we must ask, despite robust debate, why do security-threatening polices enjoy so strong a hand in Western democracies? ${ }^{133}$

\footnotetext{
129 (Qutb 2000, p. 90). See also (McCarthy 2010, p. 179).

130 (McCarthy 2010, p. 101).

131 (McCarthy 2016).

132 (Beinart 2006).

133 In Europe-which has not been the focus on this work - the undemocratic potential of parliamentary politics, with coalitions able to freeze out unwelcome parties that fall short of a parliamentary majority yet contain substantial popular support, goes some way to account for the endurance of policies that seem to expose nations to increased security risks, as does, in terms of E.U. mandates, the much mooted "democratic deficit" of the European Union in regard to certain policies. For a moderate assessment of the E.U.'s democratic deficit, see (Vesnic-Alujevic and Nacarino 2012). For a more vehement condemnation, see (Huizinga 2016, p. 194): "the E.U. has conclusively shown itself to be inherently undemocratic, unaccountable and unresponsive to voters." The E.U.'s ambitions, moreover, continue to expand, with Chancellor Merkel imploring nation
} 
Part of the answer to this question is that just as Karl Marx and Frederick Engels said of capital, so we must say of strong religious disestablishment: "it creates a world after its own image."134 Strong disestablishmentarian policies reinforce themselves by remaking political culture in a way that entrenches the stature of the strong disestablishmentarian political platform.

How can we establish such a position? The first step I maintain is to distinguish disestablishmentarian policy and disestablishmentarian political culture. Political culture is less formalistic than public law. It pertains to the broader society and to deeply rooted cultural perceptions. A strong disestablishmentarian culture reflects its policy counterpart by being largely disconnected with, indifferent toward, or even moderately hostile to the historic religion in the country, and is often multiculturalist in its orientation and wedded to social justice agendas that seek to provide some measure of compensatory advantages to adherents of minority religions. Since this cultural attitude looks at religion without any special solicitude and is associated with social justice movements attending vigorously to the status of minorities, it is a culture deeply tied to contemporary political liberalism. Recognizing this point can help us to differentiate public policy from political culture. A strong disestablishmentarian political culture, in fact, can have a formal connection between church and state yet embody the culture's values, since a state-supported church can agree that the state should be religiously neutral, and it can imbibe social justice philosophies. Indeed, in Sweden before its disestablishment the Lutheran church had been heavily disestablishmentarian in its own culture, a fact that explains in part why it presented so little obstacle to formal disestablishment, with the primate of the Church, Archbishop K. G. Hammar of Uppsala, stating, simply, "the disestablishment of the church is 'inevitable' in advanced Western nations."135

The second step in the argument is to document that the contemporary United States has a political culture defined by an increasingly robust element of strong disestablishmentarianism. The third step is to endeavor to establish a causal connection between the levels of policy and culture.

(i) Documenting the Existence of a Strong Disestablishmentarian Political Culture in the United States

In the United States, levels of irreligion are rising, especially among Millennials, those younger than Millennials, and self-identified Democrats and Liberals. ${ }^{136}$ As a doyen of historical studies, Professor Robert Louis Wilken wrote more than a decade ago: "in my lifetime we have witnessed the collapse of Christian civilization. At first the process of disintegration was slow, a gradual and persistent attrition, but today it has moved into overdrive." ${ }^{137}$ Since Wilken wrote these words in 2004, religiosity has only weakened further. Data from 58,893 respondents to the General Social Survey, a nationally representative survey of U.S. adults administered between 1972 and 2014, shows that "five times as many Americans in 2014 reported that they never prayed as did Americans in the early 1980s, and nearly twice as many said they did not believe in God."138 The number self-identifying as Christian has, correspondingly, collapsed, once again most especially among younger Americans: a 2018 Gallup survey records that 33\% of younger Americans report no religious affiliation, with a further $14 \%$ declaring themselves 'other' when presented with a list of traditional religious affiliations. ${ }^{139}$ These represent "sharp, persistent, and unprecedented declines." 140

states "today [to] be prepared to give up their sovereignty" (address to the Konrad Adenauer Foundation, 22 November 2018. Available online: www.kas.de). In relation to Brexit, one might also think of the difficulties a democratic majority has had in ensuring the realization of its freely registered will in effectuating a separation. For a more favorable view of democratic legitimacy within the E.U. see (Moravcsik 2008).

134 (Marx and Engels 1848).

135 Quoted in (The Christian Century 1999).

136 See (Lipka 2015, 2016): “Self-identified atheists tend to be aligned with the Democratic Party and with political liberalism. About two-thirds of atheists identify as Democrats (or lean in that direction), and a majority call themselves political liberals (compared with just one-in-ten who say they are conservatives)." See also (De Maio and Bolce 2002).

137 (Wilken 2004).

138 (Twenge et al. 2016).

139 (albawaba.com 2018).

140 (Twenge et al. 2016, p. 2). 
At the same time as irreligion has grown so too have acts of religious hostility. The extensive report Hostility to Religion: The Growing Threat to Religious Liberty in the United States isolates religious hostility into distinct categories, looking at acts of hostility toward religion in the public square and against religion in schools and universities, and acts of hostility toward those affirming traditional religious understandings of human sexuality. It has documented that in just three years since its first report on the topic, a $76 \%$ increase has occurred in acts of hostility toward religion in the public square and in educational venues, and a $114 \%$ increase has been seen in acts of hostility toward adherents of religiously based, traditional notions of sexuality. ${ }^{141}$ Additionally, these are just in the form of overt acts of religious hostility. As to general estimates of attitudes, the data is more difficult to quantify, but the existing research shows a similar increase. Since at least 1996, data has shown a generally rising antipathy toward Christian Fundamentalists. ${ }^{142}$ Indeed, while during the period from 2014 to 2017 Pew reports that generalized positive attitudes among Americans to atheists and Muslims spiked, they remained flat for Evangelical Christians. ${ }^{143}$

The increasing warmth of generalized attitudes toward historically marginal communities is of a piece with a rising commitment to a multiculturalist values orientation-a development that in itself in no way deserves condemnation, but which does constitute one element within the broader cluster of attitudes defining strong disestablishmentarian political culture. The trend is evidenced in at least two data points. First, it is seen in the increasing support for the value of "diversity" as such. The Pew Research Center in 2017 documents that "Nearly two-thirds of Americans (64\%) say an increasing number of people from different races, ethnic groups and nationalities in the U.S. makes the country a better place to live; fewer (29\%) think growing diversity in the country does not make much difference, and just $5 \%$ think it makes the country a worse place to live." The Center also notes that these favorable attitudes appear to be steadily rising. ${ }^{144}$ Second, it can be seen in particularized increases in support for historically less prominent religions. A majority of the general public now agree that American Muslims are an important part of the religious community in the U.S., compared to $43 \%$ who disagree, according to a report by the Public Religion Research Institute in $2011^{145}$; data from Pew indicates that this number has only increased in the intervening years. Increases in generalized attitudes of admiration are also seen in other historically less prominent religious traditions, such as Buddhism and Hinduism. ${ }^{146}$

Let me be clear: these developments are to be celebrated. Nevertheless, a critical component of the strong disestablishmentarian political culture is not just respect toward those with different religions, but the affirmation of government policies designed to give a distinct advantage to historically less prominent religious communities. Researchers at Grinnell College have documented a growing willingness among Americans to extend to Muslims accommodations in the workforce that they would not allow for Christians, such as break time for prayer. ${ }^{147}$ We should also note the persistence of public policies designed to expand preferences. Although polls on the issue have been inconsistent, ${ }^{148}$ in one Pew Research poll in 2014, 2/3 of Americans reported support for affirmative action in college admissions. ${ }^{149}$ Affirmative action in all its varieties has in turn remained a staple of American policy, with an extraordinary $84 \%$ of Democrats (and Democratic leaners) viewing affirmative action positively, according to a 2017 Pew Report. ${ }^{150}$ Moreover, despite one national poll showing 68\% disapproval

141 (Family Research Council 2017).

142 (Bolce and Maio 1999).

143 (Pew Forum 2017).

144 (Pew Research Center 2017c).

145 (Cox et al. 2011).

146 (Pew Forum 2017).

147 Available online: https://www.grinnell.edu/sites/default/files/docs/2018-12/Grinnell\%20College\%20National\%20Poll_ Nov18.pdf.

148 For one poll registering disfavor for affirmative action, see https:/ /www.wgbh.org/news/collegepollAfrimativeAction.

149 (Drake 2014).

150 (Pew Research Center 2017b). 
for the Diversity Lottery program, ${ }^{151}$ the opposition has not been so strong as to ensure its removal. The inability to eliminate, despite strong efforts, the Diversity Lottery program, whose sole raison d'etre has become to diversity the country by providing a route not available to applicants from Europe, testifies to the power of minority preference. ${ }^{152}$

(ii) Creating a World: The Causal Inference

Some have questioned the influence of church/state policy on the American population. Christopher Eisgruber, for one, argues that the establishment clause rulings of the Supreme Court in the post-War period have had a minimal effect on religiosity or on the general public's attitude to religion and religious life. ${ }^{153}$ How then can we establish a strong claim for this point? I propose three ways. We can ask, (a) Can we defend the plausibility of factors associated with strong disestablishment serving as causal drivers in the social change that we have sketched?; (b) Does social reality look the way it would need to look for the casual claim to be defensible, by at least the increase in irreligiosity coming after the creation of the strong disestablishmentarian policies?; (c) related to this, Are there examples in the other direction, that is, cases where a once secular society implements public laws favorable to religion and in turn sees an increase in religiosity after the implementation?

\section{(a) Justifying Causal Plausibility}

For the theory proposed initially to be defensible we would need to justify the plausibility of seeing strong disestablishmentarian policies as causally effective, that is, as plausible forces that could support what Walker has alleged to be the "culturally transformative power of American liberalism."154 I develop the plausibility of seeing three core elements of the changes associated with strong disestablishment as causative factors in a dramatic degree of social and cultural change. To be sure, I do not attempt to defend the claim, implausible on its face, that these factors are the only drivers, but only that they are genuinely plausible causal forces in regard to social and cultural transformation. . $^{155}$

First, immigration has been a core element of the theory of strong disestablishmentarianism, justified among policy elites, as we saw, as a "milestone in the telos of American liberal pluralism."156 Should it be seen as a plausible causal driver in attitudinal changes such that it can be held partially to engender a transformation in political culture? Trigg provides some of the strongest arguments that it can in his work on diversity, philosophy, and relativism. Although, philosophically, "religion makes claims about an objective reality that holds for us whether or not we are willing or able to recognize it ... and its seriousness and importance depends on this," ${ }^{157}$ society is not comprised of philosophers. As Trigg argues, for many "the fact of diversity suggests it is a matter of chance that one grew up in one country or home, with one set of beliefs, rather than another, with a different set." ${ }^{158}$ Trigg also references the importance for society of even stronger positions on diversity and its acidic effect on religious conviction. Robert McKim, for example, calls the fact of religious diversity "a challenge to orthodoxy." ${ }^{159}$ Steve Bruce even goes so far as to call it, in the eyes of true believers,

\footnotetext{
151 http://harvardharrispoll.com/wp-content/uploads/2018/01/Final_HHP_Jan2018-Refield_RegisteredVoters_XTab.pdf.

152 The program was set for termination in 2013, for example, but was not eliminated. "Congress tried unsuccessfully several times since 2005 to end the program" (Fox News 2017). On its religious impact see Pew Reports from as early as 2012 noting a "growing share of legal Immigrants belong to minority religions" (Pew Research Center 2013).

153 (Eisgruber 2006). For a European expression of doubt, see the reports of Observatoire des Religions et de la Laicite, especially at http://www.o-re-la.org/index.php/eu-countires/item/1333-belgium.

154 (Walker 2000, p. 113).

155 Other factors would seem to include the development of a highly secular multi-billion dollar entertainment industry, itself only possible if there is the high level of "existential security" that Pippa Norris and Ronald Inglehart hypothesize is a major contribution to secularization. See (Norris and Inglehart 2004). A crisis relating to sex abuse by Catholic priests cannot help, either.

156 (Ngai 2004, p. 263).

157 (Trigg 2014, p. 41).

158 (Trigg 2014, p. 63).

159 (McKim 2001, p. 204; Trigg 2014, pp. 84, 89). See also, (McKim 2012).
} 
a "cancer," as it debases religion to the consumerist level of whimsical choice. ${ }^{160}$ Trigg elaborates on these points by seeing diversity as necessarily highlighting religion as a personal choice among an array of menu items. For, "choice can dissolve into subjective preference and reduce the importance of what is chosen." 161 Further, for many individuals, choice is magnified even more when there is stark competition among different or even diametrically opposed religious ideas. In all, for many in the wider society, "increasing religious diversity can set a society on a trajectory that leads to it becoming more suspicious of religious claims." 162

Second, reforming education has been a core aspect of strong disestablishmentarianism. Not in vain, perhaps, did the Psalmist write: "we shall not hide the truth from our children."163 Long too has been voiced that Jesuit chestnut, 'let me shape the boy, and I'll show you the man.' Walker in fact states the potential transformative prowess of a strongly disestablishmentarian educational policy as follows:

American judges committed to this approach often mention the impressionability of young children as one of the natural facts that necessitate a secular neutralist approach, especially in education ... such judges act, they say, on behalf of impressionable children, whose liberty of conscience must be protected from the powerful pressure of politically-sanctioned religion. But such judges-and the legal theorist whose ideas support them-are strangely oblivious to the reverse implication of impressionability. Children are indeed impressionable, but for that reason they are deeply susceptible to the politically sanctioned absence of God, to the state-sponsored refusal to recognize, in public or common life, God's relevance and His claims. What habits of mind does this induce in impressionable children (who grow up to be adults)? It induces either a discomfort with talk of God, as something unfamiliar, or else it induces a tendency among religious believers to regard their beliefs as true only in a private sense: 'it's true for me, but not necessarily for you.' [As a result ... ] more than anyone else, the person with a secularist [ ... ] outlook [on life] feels perfectly at home in, and psychologically and rhetorically equipped for success in, the constitutional regime of secular neutralism. 164

Third, the federal court's case law effectuating strong disestablishment as well as public pronouncements by government officials have the potential to produce an independent causal effect. To see how this is so we must first survey, by way of review, the public statements that accompany strong disestablishment. We can then work to establish that the messages have a potentially substantial social and cultural impact.

$(\alpha)$ Reminding Ourselves of the Strong Disestablishmentarian Public Message

The messages of law and public policy concerning religion under a system of strong disestablishment have the following features. As to the strict separationist component, as Trigg remarks, "a liberal state that stands apart from religion, thinking it is a purely individual matter, is saying that politics must be entirely independent of religion, and that religious principles have nothing to say to the real world of political action"165 — a world in which the grave matters of life, death, war, peace, medicine, housing and sustenance are each involved. Hence, religion is communicated as itself not a grave or important matter. Through strict separation, therefore, "the message is being transmitted by the organs of State that religion is a completely optional, and dispensable, part of human life,"166 and, as part of this, "that it does not matter whether Christianity is true or false."167 All that matters is

\footnotetext{
160 (Bruce 1999, p. 186).

161 (Trigg 2014, p. 155)

162 (Trigg 2014, p. 162).

163 Psalm 78:3. New International Version.

164 (Walker 2000, p. 112).

165 (Trigg 2008, pp. 113-14).

166 (Trigg 2008, p. 119)

167 (Trigg 2008, p. 221).
} 
that the state not act in the manner of a Yemelyan Yaroslavsky; that religion not be driven to death by a state-led league of the Militant Godless.

Furthermore, by "distancing itself from all religious beliefs, the state has to treat them all equally, inevitably assuming that none of them can be particular repositories of truth." ${ }^{168}$ Hence strict separation will invariably communicate a relativism that will allow ideas into the public square under the putative auspices of 'freedom of religion or belief or conscience' that make a mockery of religious life. Unsurprisingly has the neutralist state recently allowed Satanic symbols to be promoted in the public square, and not under freedom of speech, but freedom of religion-a development that can only further stigmatize religion as radically subjective, groundless, and irrational, as reason could never countenance Satan, at least as conventionally defined: the father of all lies and the enemy of all rationality. Of course, individuals might have a recherché definition of the devil, as an embodiment of toleration and enlightenment, but why, then, this unconventional usage and not a more accurate designation? As such, religion is simply "private prejudice." 169 And as prejudice, it "becomes something to be managed, controlled, and ultimately ignored." ${ }^{170}$ In turn, the state "devalues its right to be heard or lived by."171

This messaging has been echoed by the less influential but still not inconsequential work of legal scholars. Indeed, concerned with the history of race and with expansive conceptions of equality in the present, Yale University professor Tisa Wenger argues that religious freedom "is not self-evident." That professors at what were once the training grounds for the defenders of the traditional faith now assert that religious freedom, once included among the "self-evident" rights of every person at the time of the founding, is now, in near-Calhounian repudiation, "not self-evident," but to be thrust beneath "a hermeneutic of suspicion," casts an ominous signal. ${ }^{172}$

\section{( $\beta$ ) Does Messaging Matter?}

The question remains as to whether the messaging effect of public laws embedding strong disestablishment really matters. To the contrary, the normative force of law can be seen in the everyday inference that, if something were really important, there would be a law about it. As Trigg notes in regard to public education, "no state leaves it to chance which 'values' are imbued by children."173 What is more, as Brendan Sweetman relates, no organization committed to effectuating its ideals runs from at least some measure of state endorsement. The Humane Society, for example, would never

168 (Trigg 2014, p. 165).

169 (Trigg 2014, p. 167).

170 (Trigg 2014, p. 168). Relevant to this discussion is the fact that in Sweden as disestablishment has taken hold, the Lutheran church has come to be increasingly—not decreasingly—subject to governmental control. See https:/ /www.rwarchives.com/ 2011/11/church-sweden-disestablished-increasingly-politicized/.

171 (Trigg 2014, p. 167). Canadian and European legal decisions are often even more explicit in their public messages. For example, in the provincial court in Quebec the court held that "given the religious diversity of present-day Quebec, the state can no longer promote a vision of society ... that is based on the historically dominant religion." S.L. et al v. Commission Scolaire des chenes et al. (2012 SCC7, 426 N.R. 2012, 352-83, para. 10) The fact of pluralism is expressed as controlling in matters of traditional religion, which must accommodate itself to the present-day pluralism. However, new arrivals who have contributed to the fact of pluralism are not told that traditional norms of, for example, gender equality are no longer to be promoted now that some diverse communities endorse stringent gender segregation: here what is traditional is held up as something the new arrivals must unceasingly respect. Not so for traditional religion. Why? It seems hard not to detect that the message being sent is that traditional religion is less important than other well established principles, including gender equality. The former is sotte voce upheld as non-rational and relativistic, while the latter is declared to be paramount. Even more explicitly, in the case of McFarlane v. Relate Avon Ltd (2010) the Court of Appeals for England and Wales, in an opinion by Lord Justice Laws, makes a "sweeping" claim about "the nature of religion as such" (Trigg 2013a, p. 144) —entering "a centuries-old debate about the respective roles of faith and reason" (Trigg 2014, p. 17). Lord Laws writes that "in the eye of everyone save the religious believer religious faith is necessarily subjective, being incommunicable by any kind of proof or evidence," and has no place in a "reasonable society." Hence to prefer a position which has any religious admixture is in his mind simply "irrational, as preferring the subjective over the objective" (paras. 23, 24). Hence, "religion cannot embody any knowledge" (Trigg 2008, p. 191). As Trigg accurately summarizes, this declaration by the state can only "denigrate religion" (Trigg 2013a, p. 156).

172 (Wenger 2013).

173 (Trigg 2008, p. 122). 
avoid state endorsement of standards of animal treatment on the grounds that state endorsement would water down its witness, or would render its message "toxic." Hence, as Sweetman remarks, we all "wish to influence the state, the culture, and especially the law, by means of some of our beliefs. All of us want to do this no matter what our worldview." ${ }^{174}$ Hadley Arkes in his seminal work, First Things: An Inquiry into the First Principles of Morals and Justice, puts the point starkly: "law has an enormous influence on social norms and individual conduct in society. That is the point."175

What is more, the political left has made powerful arguments recently for the importance of governmental messaging, and has done so in a four-fold manner. First, it has highlighted the power of messaging through a fairly abstract discussion about social cognition; second it has done the same in its more concrete condemnations of statements by the Trump administration; and, lastly, two policy initiatives of the Obama presidency predicated on the power of government messages to effectuate social change underscore the point.

First, as Walker astutely points out, the claim I am developing is in accord with contemporary left-leaning postmodernist doctrine, a philosophical vantage point holding that "consciousness is 'socially constructed.'”176

Second, and more concretely, the claim about the efficacy of government messages is now regnant among the political left. Trump's actions and even his tweets, we are now told, are-no matter how remote they may be from most people's ordinary lives- "harms" to American culture. Take the issue of a ban on transgender military personnel, which at the very most would impact about 15,500 people in a nation of 320 million ${ }^{177}$ (and arguably is supported by at least facially plausible arguments about readiness and military costs). Despite the narrow application of the executive order in question, government messaging deeply matters, we are told. Widely cited "hate expert" Linda M. Woolf writes in the poplar academic magazine Psychology Today the following on the power of government words: "On a broader level, the President's actions send a message to all citizens within the U.S. and abroad, that discrimination and prejudice against transgender and other gender-variant individuals are appropriate. Federal policies of discrimination fuel a culture of bias and intolerance."178 This from an ordinance extremely remote from the vast majority of Americans, so powerful is government messaging seen to be.

Third, if we fail to credit the potency of government declarations a paradox besets the initiatives of the previous administration. President Obama sought through addresses to global audiences, in Cairo, at the United Nations General Assembly, and across the world, to through the power of words assuage concerns of Muslims at home and abroad "that America is not at war with Islam." He sought also through the efforts of the National Aeronautics and Space Administration to tell members of the Muslim world "to feel good about their historic contribution to science, math, and engineering."179 Can the only slightly less declarative words of "that eminent tribunal"180 be seen as innocuous, while messaging to the Muslim world is heralded as highly impactful? ${ }^{181}$

Government messaging, it would seem, matters.

(b) Does Social Reality Look the Way it Must?

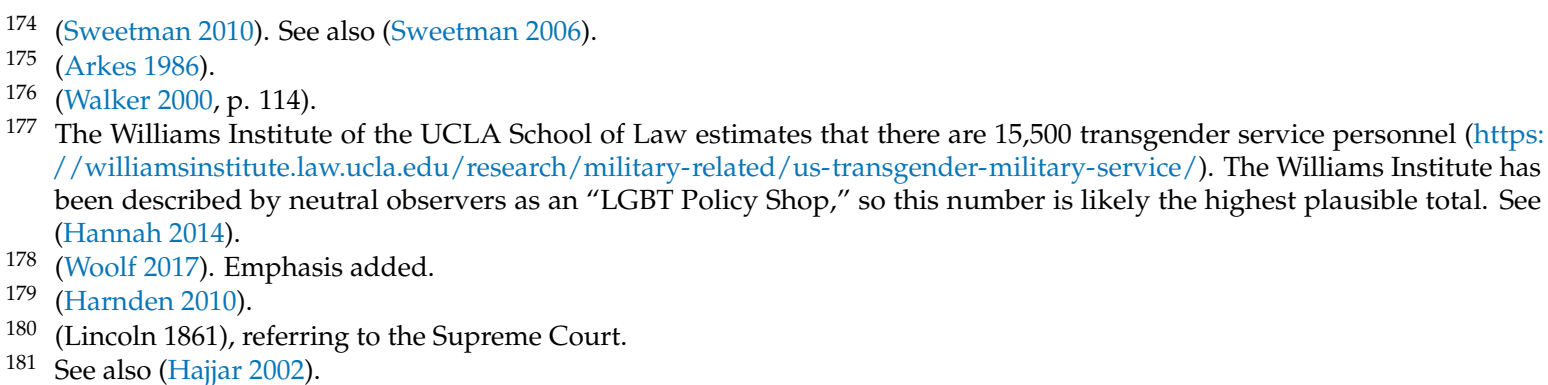


Although the drivers identified above are such that it seems plausible to hypothesize that they are causally related to a distinctive political culture, another set of conditions must also be present to reinforce the inference. It must be the case that the disestablishmentarian policies were first developed either as measures by the politically accountable branches of government but in ways that did not specifically intend to create the factors that make up strong disestablishmentarian culture, or, if so, were not heavily publicized at the time, or were developed under a cloud of great political controversy, or, lastly, were imposed by democratically unaccountable courts or administrative agencies. Either or all of these must be the case to rule out the inference that the measures were products of a preexisting broad-based demand, for if they were, then the causal arrow must point from culture to policy and not in the opposite direction; the laws would be functions, not causes. ${ }^{182}$ Associated with this, the rise in the hypothesized outcome must, of course, be temporally subsequent to the causal drivers themselves. These factors do in fact each align in the manner required by the theory.

First, as to immigration, the 1965 immigration reform law reflected a policy decision by government elites expressing a progressive ideology; however, it is important to see that the diversification of the country that has resulted was mostly unintended. One of the chief architects of the reform law, Massachusetts Senator Edward Kennedy, told the American people in no uncertain terms that "the ethnic mix of this country will not be upset." 183 He did not dissimulate. Many at the time thought the legislation would not have a large demographic impact, and its focus was initially on modest changes to the then existing national quota system for the purpose of ensuring immigration by highly qualified workers in technical fields of employment, without reference to sweeping changes in national demographics. In fact, one of the law's key provisions was actually put into the bill to ensure precisely that its impact would remain minimal: family unification. Family re-unification as a basis for immigration reform was presented by opponents of the bill, especially House Immigration Subcommittee Chairman Michael Feighan of Ohio, as a way to ensure that migration would not upset the country's demographic composition. It was thought by Feighan that family unification would solidify the nation's demographic status quo. It turned out, however, that family restoration had a massive effect on immigration levels, leading to profound, and unanticipated, change. ${ }^{184}$ Additionally, the Diversity Lottery initiated in 1990 was initially trumpeted as a way to deal with high levels of illegal Irish immigration. It only later and without considerable public commentary transitioned into a facilitator of Third World-intensive immigration. As Patricia Alvarez notes, "The history of the green-card lottery is a story of unintended consequences." 185

As to the American system of public education, the changes effectuated in this area were very often the direct results of rulings of the electorally unaccountable federal judiciary.

In terms of multiculturalism, the Civil Rights Movement doubtless had a profound impact on considerations of public justice, yet the dismantling of unjustifiable segregation preceded the contemporary focus of many on multicultural advocacy.

Lastly, the timing of the rise of secularism corroborates our theory. A 2016 Pew Report finds that

182 Philip Hamburger develops a somewhat different assessment in Separation of Church and State. Hamburger presents the judicially imposed strict separationism as the function of a rising anti-Catholic and anti-institutional strain in widely believed American liberal Protestantism. Hamburger's account has much to commend it. However the core of the argument here developed is not gainsaid by Hamburger's masterful history. As Hamburger acknowledges, "many relatively traditional Protestants felt stunned" by the McCollum decision banning voluntary participation in in-school religious release time programs. "They had sought their familiar Protestant [form of] separation and now suddenly found themselves confronted with a secular version, which threatened the nonsectarian religiosity of America's public institutions" (Hamburger 2002, p. 47). Emphasis added. What Hamburger sees growing in strength across American history is not strong disestablishment per se, but a more limited internecine dispute about how religion should positively inform public life, not the more sweeping question, answered in the negative by strong disestablishmentarians, of whether a generic, minimal Christian theism should infuse the operations of governance and the laws by which a society seeks to organize itself.

183 Quoted in (Hing 2012, p. 95).

184 (Gjelten 2015).

185 (Alvarez 2017). 
while the overall decline in the country's religiosity is driven partly by modest declines among Baby Boomers and those who are part of the Silent and Greatest generations [generations impacted less profoundly by strong disestablishment], generational replacement appears to be an even larger factor. In other words, Millennials, who make up a growing share of the population [and who bear the greatest brunt of strong disestablishmentarianism] as they reach adulthood and older Americans die off, are far less religiously observant than the older cohorts. Whether Millennials will become more religious as they age remains to be seen, but there is nothing in our data to suggest that Millennials or members of Generation $X$ have become any more religious in recent years. If anything, they have so far become less religious as they have aged. ${ }^{186}$

Secularity is relatively recent, with the disestablishmentarian laws coming mostly before the increases in irreligion evident in the United States. The world very much looks as the world must for the theory to gain credence.

\section{(c) Examples in the Other Direction}

The theory however would hold even greater credibility were we also able to demonstrate examples of laws expressive of weak disestablishment being implemented de novo in highly secular societies exposed to strong or even extreme disestablishment followed by indicators of a subsequent transition in those secular cultures to higher levels of religious belief and practice. The recent history of Ukraine provides one such an example. In 1991, following the collapse of the Soviet Union, the region had very low levels of religiosity. A Pew Report in 1991 documented that only 39\% then described themselves as Orthodox. ${ }^{187}$ In 1991, however, Ukrainian elites drafted a constitution that contained within it principles embodying something very close to the classic American model of weak disestablishment. As Professor Gennadiy Druzenko reports, at the time of drafting and ever since, "Most Ukrainian experts and scholars ... acknowledge that separation of Church and State is an indisputable foundation" of a just society, while at the same time "scholars and experts generally concur with the opinion that education, charities (particularly social rehabilitation), and the conservation and maintenance of religious-cultural heritage sites are proper spheres for effective state-church cooperation." 188 What this means is a repudiation of both extreme and strong forms of religious disestablishment.

In turn, by 2015 the Pew Forum reported that $78 \%$ of the Ukrainian population now describe themselves as Orthodox. Additionally, when asked in 2014 whether they saw their country in the 1970s as very or somewhat religious, only $15 \%$ said they did, while $59 \%$ said their country is now either very or at least somewhat religious - a remarkable cultural transformation. As Pew summarizes the data: "the comeback of religion in a region once dominated by atheist regimes is striking-particularly in some historically Orthodox countries [such as Ukraine], where levels of religious affiliation have risen substantially in recent decades." 189

To be sure, tensions with Russia have increased since 2014, when Russia occupied Crimea, which was then a part of the Ukraine, and religious sentiments might therefore bespeak a "rally around the flag" effect. Importantly, however, this data precedes those tensions: a mere unreflective return to Ukrainian Orthodoxy as a marker of anti-Russian sentiment thus cannot be more than a partial component of the remarkable re-energizing of religious vitality. Indeed, reports from Ukraine relate that religion is not strongly indexed to nationalism. Cyril Danilchenko of the Euro-Asian Jewish Congress relates that "the Orthodox faith doesn't inform Ukrainian nationalism to the same degree as

\footnotetext{
186 (Smith and Cooperman 2016). See also, (Lipka 2015).

187 (Pew Research Center 2017a).

188 (Druzenko 2010, pp. 21, 25).

189 (Pew Research Center 2017a).
} 
Russian nationalism ... In Ukraine ... faith is more of a personal affair. You don't hear slogans like 'we are Ukraine, we are Orthodox!'”190

Nevertheless, even if there were elements of nationalism in the Ukrainian religious revival, certainly nationalism is facilitated by government messaging, ${ }^{191}$ underscoring in turn how the causal driver of government signaling can engender religious vigor. ${ }^{192}$ Once again, although the data is merely correlational, it is just what one would expect if the causal inference were true.

In all, it seems highly likely that law, public policy, and political rhetoric have contributed to creating "a massive cultural transformation by means of strict separationist"193 disestablishmentarianism: A world has been created.

\section{Defending Weak Disestablishment}

The arguments so far developed are important for on-going debates over the position of religion in public life in Western democracies. They should inform the question of how we should interpret the United States Constitution's forbidding of "laws respecting an establishment of religion or prohibiting the free exercise thereof." Should the High Court in the words of Philip Hamburger "repudiate separation," and thus also "repudiate any pursuit of separation in terms of 'substantive neutrality' and government's role as 'neutral'"? 194 Should the Court restore the pre-War doctrines of weak disestablishment? Justice Clarence Thomas for one has been especially supportive of rolling back America's post-War disestablishment. ${ }^{195}$ On the other hand, should either the status quo of explicit recognition under law of religious neutralism (and its associated reduction of religion to a personal matter subject to minimization in the face of other state demands) be maintained, or even developed further, as Leiter, Sehat, and Sullivan among other seem to espouse, perhaps by revoking the tax-exempt status of religious associations, or by limiting further the rights to religious accommodation, or by purging the Pledge of Allegiance of the offending words "under God"? 196 In Europe, should religious establishments where they still exist formally be abolished? ${ }^{197}$

These issues for Justice Thomas are matters of constitutional interpretation. For individuals outside the judiciary, however, the questions are ones of political and legal philosophy. Even if we agree as a matter of law that weak disestablishment should be reinstated, as a matter of political reality the question can for us only be, how do we persuade the individuals who select justices-be they the senators who do so directly or the voting public which does so indirectly-that the Court must be

190 Quoted in (Kozioff 2015).

191 See for example (Tilly 1994).

192 See also (Goodenough 2018).

193 (Walker 2000, p. 122).

194 (Hamburger 2004, p. 190).

195 If the Court will were not to do this and the case law were to stand opponents might go even further and espouse an amendment to the Constitution to establish what Graham Walker calls a "partial establishment," a system authorizing in constitutional law explicit state endorsement at least of religion as a whole but even possibly of a specific denomination, while firmly upholding religious freedom and the right to dissent (Walker 2000, p. 118). See also his astute point that dissent could even be thought to be enhanced in such a regime, making such an amendment perhaps "the most potent basis of dissent," if for no other reason than that a government stand on the basis of religion underscores truth seeking, and a high prize on truth seeking can invigorate moral and political debate, discussion, and dissent (Walker 2000, p. 121). Trigg alludes to this point too by saying "the Establishment of the Church of England has never inhibited [religious] diversity" (Trigg 2014, p. 161).

196 See (Nussbaum 2008). This is also the view which the 9th Circuit Court of Appeals affirmed in Elk Grove Unified School District v. Newdow, 542 U.S. 1, 45-46 (2004). The case was overturned by the Supreme Court on a technicality relating to standing, but the issue will eventually come to the Court on its merits.

197 For movements to formally disestablish the Church of England, see the 2017 manifesto of the National Secular Society, "Separating Church and State: The Case for Disestablishment," available online: https:/ /www.secularism.org.uk/uploads/ nss-disestablishment-report-2017-3.pdf. For arguments against a broadened establishment formally including a variety faiths, see also (Toynbee 2010) arguing against any establishment of religions "on principle because it excludes the large and growing non-religious population." Trigg also points out the attack on state support for religion in countries with "strong religious traditions," such as Ireland and Malta (Trigg 2013a, p. 37). 
manned with individuals whose originalism would result in this position? This becomes inevitably a question of political and legal theory.

How do we begin to address the normative question of weak disestablishment? Normative theory, I believe, must respond to real world indicators. For the goal of political and moral philosophy is for it to have a robust relevance to public policy. Here the recent work of philosopher Jonathan Wolff is important. In his book Ethics and Public Policy: A Philosophical Inquiry Wolff argues for an approach to philosophy that rejects "grand theorizing" without respect to the practicability of one's conclusions. Wolff argues instead that room must be made for an approach to political and moral philosophy that adjusts philosophical argument in light of the practical applicability and tangible characteristics of the views at hand. ${ }^{198}$ Within this framework, how can the argument for weak disestablishment best be made? I develop five elements of a partial defense of the system of weak disestablishment.

\section{(i) First, Pay Special Attention to Long Term Effects}

Policies need to be doubly vetted because of their self-embedding and reinforcing nature, making them hard to unwind once in place. This heightens the importance of the arguments respecting the roles of church and state.

(ii) In this Light, See Freedom of Religion as a Core Value and a Means of Avoiding a Liberal Paradox

What I am arguing for is resisting strong disestablishment-not a coercive form of establishment destructive of religious liberty. Freedom for all religions always deserves consideration. However, liberalism risks embedding a paradox: it professes to be supportive of minority communities under auspices of its strong disestablishmentarian multiculturalism. Yet its own inner dynamic can unleash currents that undermine all religion, including the minority traditions liberalism professes to protect. This can occur for at least three reasons. First, there is no basis at all to suggest that the problems we have identified about the corrosive impact of strict separationism would attach only to the majority religion, although the majority religion is liberalism's primary target: the corrosion likely will spread into a critique of every religion, engendering indifference to religious life as such. "Secular thinking," Trigg remarks, "caught up with issues concerning equality and non-discrimination, treats its own views as superior to any religion. ${ }^{\prime 199}$ And liberalism in fact can do more than facilitate indifferentism. "An avowedly secular society may be prepared to tolerate religion," Trigg alerts us, "but it will also wish to marginalize it." ${ }^{\prime 200}$ More menacingly, still, "the path from official neutrality to indifference, and then hostility, to religion can be surprisingly short." ${ }^{201}$ Minority religions over time will fail to prosper in a climate of strong disestablishment-and they will suffer all the more should strong disestablishment bleed into its extreme form, as the Soviet Union's tragic persecution of Jews and Muslims amply attests. ${ }^{202}$

(iii) See Both Religious Freedom and Traditional Religiosity as Anchors of State-recognized Human Dignity in all Areas of Life

Religious freedom entails human dignity which can ground other rights and protections: religious freedom can be seen as an anchor, or a "root" of all personal freedoms. As Trigg argues, "religious liberty is not contrary to human rights, but an integral part of our understanding of what human rights are," for "religious freedom goes to the heart of human rights" and "has to be at the root of any democracy," for implied within it is the very power "that makes democratic consent possible in the

198 (Wolf 2011, pp. 191-208).

199 (Trigg 2013a, p. 133). Emphasis added.

200 (Trigg 2008, p. 23).

201 (Trigg 2008, p. 235).

202 "In the early 1920s, the Soviet government effectively banned Islam in Central Asia. Books written in Arabic were burned, and Muslims weren't allowed to hold office. Koranic tribunals and schools were shuttered, and conducting Muslim rituals became impossible. In 1912, there were about 26,000 mosques in Central Asia. By 1941, there were just 1000" (Erickson 2017). 
first place."203 Indeed religious freedom is "crucial for all freedom, [for] without the ability to decide, and live by, what we consider to be most important and valuable in human life, we cannot be free."204 So protecting religious liberty flows into the protection of a wider array of freedoms.

At the same time, traditional Judeo-Christian religion enjoins respect for human dignity and has a self-regulating character that further enshrines respect for religious difference. Trinitarian Christianity "by definition deals with what goes beyond our understanding," Trigg notes, and does so "in the most comprehensive sense." As such, "humility, even humility toward the truth, is a religious virtue" in Christian thought. ${ }^{205}$ A measured support by the state for Judeo-Christian traditions can therefore underscore a state's commitment to enduring rights and freedoms.

\section{(iv) Recognize that Security Complements the Dignity of Individuals}

Strong disestablishment weakens the security of the public from violent religious extremism. Security, however, is not an enemy of human dignity. Right-wing extremism is. Enhancing security protects individuals from an excrescence of right-wing extremists. A 2017 report by Dame Louise Casey of the House of Lords concludes that a security-imperiling political correctness can only empower the far right-the true enemies of human dignity. ${ }^{206}$ Douglas Murray states this point well: "Europeans have been deflating the language of fascism when they might need it ... There are truly fascist parties such as Ataka in Bulgaria or Golden Dawn in Greece" that deserve our attention as we endeavor to uphold the highest standards of human rights and human dignity. ${ }^{207}$

Moreover, if security-eroding policies are left unchecked-if, for example, in Murray's words, "you pretend long enough, in the face of clear evidence, that all the immigrant arrivals are asylum seekers" - then "you will eventually spawn a movement that believes none of them are." 208 Thus the genuine exigencies of those in need can be dismissed out of hand-no victory for dignity. Additionally, as a result of miscalculations and possible prevarications by government elites over immigration policies pursued in furtherance of a multiculturist agenda, "more than a quarter of people believe MPs never tell the truth about immigration," 209 a discovery the poll's sponsor, the think tank British Future, describes as "quite shocking." And rightly so, as the broad failure of trust in state institutions cannot auger well for the health of government policies designed to advance human rights and human dignity.

Finally, we should view the relations between church and state through a renewed application of the Hierarchy of Needs developed by psychologist Abraham Maslow. Maslow formulated in his classic 1943 work "A Theory of Human Motivation" an influential approach to individual fulfillment: individual dignity requires first the satisfaction of physiological needs and safety before higher constituents of human flourishing can consistently be enjoyed. ${ }^{210}$ Security, therefore, provides an indispensable precondition to a richly satisfying, truly dignified life.

(v) Cast Strong Disestablishment under a Pall

In closing, law professor and secular activist Erwin Chemerinsky recently announced, "The thesis of my remarks is a simple one: Now more than ever, we need the Freedom from Religion Foundation."211 The Freedom from Religion Foundation has led the way in activism to remove religious life from public affairs and to minimize the constitutional birth-right of religious freedom. It is a sentinel of strong disestablishment. In this work I have endeavored to defend the centrality of

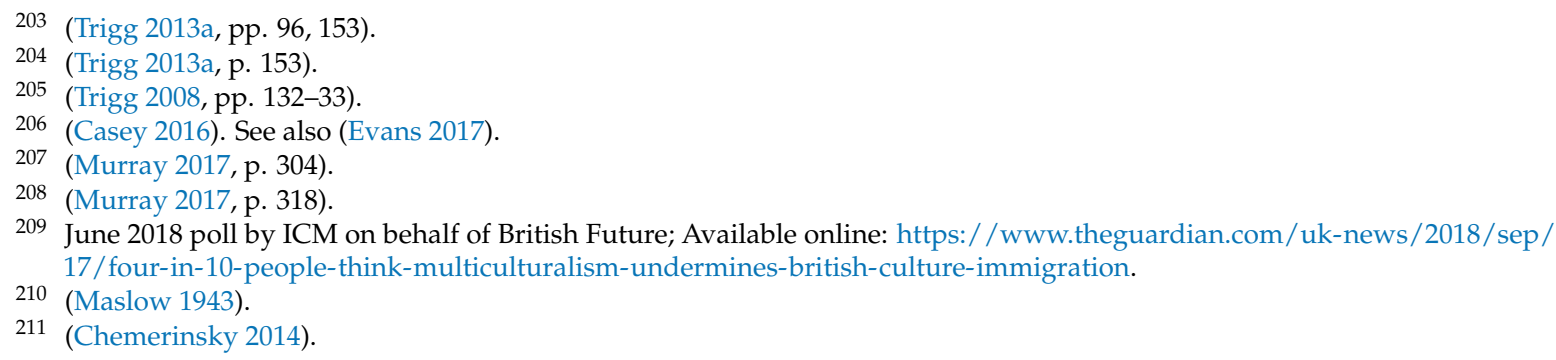


religious liberty within a system of law and public policy that expresses the traditional norm in the United States of a positive, cooperative relationship between religious organizations and the state-a system I have labelled weak disestablishment. Its repudiation in the form of strong disestablishment, I hope to have established, is associated with a weakening of security from violent religious extremism and it jeopardies our broader commitment to individual liberty and human dignity. Pace Chemerinsky, now more than ever, we need less divisive agitation condemning the religious heritage of our nation, and a return to constitutional norms.

Funding: This research received no external funding.

Conflicts of Interest: The author declares no conflicts of interest.

\section{References}

Abernathy, Ralph David. 1990. And the Walls Came Tumbling Down: An Autobiography. New York: Harper Perennial. Acheson, Ian. 2018. Prevent Let the Parsons Green Bomber through the Net. That Can't Happen Again. The Guardian, March 28. Available online: https:/ / www.theguardian.com/commentisfree/2018/mar/28/ prevent-parsons-green-bomber-counter-terrorism (accessed on 28 December 2018).

Adams, Arlin M., and Charles J. Emmerich. 1989. A Heritage of Religious liberty. University of Pennsylvania Law Review 137: 1559-671. [CrossRef]

albawaba.com. 2018. Gallup: Church Attendance in U.S. Is on Steep Decline over Past Decade. albawaba.com, April 10. Available online: https:/ / www.albawaba.com/editorchoice/gallup-church-attendance-us-steep-declineover-past-decade-1115128?utm_source=The+Witherspoon+Institute\&utm_campaign=77fd8d4ceb-RSS_ EMAIL_CAMPAIGN\&utm_medium=email\&utm_term=0_15ce6af37b-77fd8d4ceb-84110661 (accessed on 29 December 2018).

Ali, Safia Samee. 2016. Border Protection's Social Media Proposal Comes under Fire. NBC News, July 19. Available online: https:/ / www.nbcnews.com/storyline/san-bernardino-shooting/border-patrol-s-socialmedia-proposal-comes-under-fire-n602671 (accessed on 27 December 2018).

Alvarez, Patricia. 2017. The History of the Green-card Lottery, Attacked by President Trump on Wednesday, Is a Story of Unintended Consequences. The Atlantic, November 1. Available online: https://www.theatlantic. com/politics/archive/2017/11/diversity-visa-program/544646/ (accessed on 27 December 2018).

Arkes, Hadley. 1986. First Things: An Inquiry into the First Principles of Morals and Justice. Princeton: Princeton University Press.

Associated Press. 2012. FBI Did Not Investigate Fort Hood Shooter because of Political Correctness, Report Says. Associated Press, July 19. Available online: https:/ / www.foxnews.com/us/fbi-did-not-investigate-fort-hoodshooter-because-of-political-correctness-report-says (accessed on 28 December 2018).

Bedard, Paul. 2016. Sessions: 65\% of All Terror Convicts Were Foreign Born; Half from Muslim Nations. Washington Examiner, June 22. Available online: https:/ / www.washingtonexaminer.com/sessions-65-of-allterror-convicts-were-foreign-born-half-from-muslim-nations (accessed on 1 December 2018).

Beinart, Peter. 2006. The Good Fight: Why Liberals—and Only Liberals-Can Win the War on Terror. New York: HarperCollins.

Benkof, David. 2017. No, Orthodox Jews Cannot 'Just Send their Kids to Public Schools'. Jewish Journal, February 6. Available online: https://jewishjournal.com/opinion/david_benkof/214412/no-orthodox-jews-cannotjust-send-kids-public-school/ (accessed on 1 December 2018).

Berman, Paul. 2003. The Philosopher of Islamic Terrorism. The New York Times Magazine, March 23. Available online: https:/ / www.nytimes.com/2003/03/23/magazine/the-philosopher-of-islamic-terror. html (accessed on 1 December 2018).

Besson, Sylvian. 2005. La Conquete de l'Occident: Le Projet Secret des Islamites. Paris: Seuil.

Blake, Mariah. 2013. Internal Documents Reveal How the FBI Blew Fort Hood. Mother Jones, August 27. Available online: https: / www.motherjones.com/politics/2013/08/nidal-hasan-anwar-awlaki-emails-fbi-fort-hood (accessed on 1 December 2018).

Bolce, Louis, and Gerald De Maio. 1999. Religious Outlook, Culture war Politics, and Antipathy toward Christian Fundamentalists. The Public Opinion Quarterly 63: 29-61. [CrossRef] 
Bond, Brian. 2010. President Obama: It Gets Better. October 21. Available online: https: / obamawhitehouse. archives.gov/blog/2010/10/21/president-obama-it-gets-better (accessed on 1 December 2018).

Bradney, Anthony. 2010. Religion and the Secular State in the United Kingdom. In Religion and the Secular State: Interim Reports. Edited by Cole Durham and J. Martinez-Torron. Provo: Brigham Young University, International Center for Law and Religion Studies.

Brown, Michael. 2012. Dan Savage Savages the Bible, Christianity and the Pope. townhall.com, May 2. Available online: https:/ / townhall.com/columnists/michaelbrown/2012/05/02/dan-savage-savages-thebible-christianity-and-the-pope-part-i-n1091313 (accessed on 1 December 2018).

Brown, Elizabeth Nolan. 2015. Hit and Run Blog. reason.com, December 16. Available online: https:/ /www.reason. $\mathrm{com} / \mathrm{blog} / 2015 / 12 / 16 /$ social-media-dhs-and-isis (accessed on 15 December 2018).

Bruce, Steve. 1999. Choice and Religion: A Critique of Rational Choice. Oxford: Oxford University Press.

Bruno, Bianca. 2018. Judge Declines to Block anti-Islamophobia Effort in San Diego Schools. Courtroom News Service, September 25. Available online: https:/ / www.courthousenews.com/judge-declines-to-block-antiislamophobia-effort-in-san-diego-schools / (accessed on 28 December 2018).

Campbell, Wesley J. 2012. Religious Neutrality in the Early Republic. Regent University Law Review 24: 318.

Campbell, Alexia Fernandez. 2014. The City that Offers Sharia-Compliant Loans to Muslim Business Owners. The Atlantic, June 30. Available online: https:/ / www.theatlantic.com/politics/archive/2014/06/the-city-thatoffers-sharia-compliant-loans-to-muslim-business-owners/431079/ (accessed on 1 December 2018).

Casey, Dame Louise. 2016. The Casey Review: A Review into Opportunity and Integration. December. Available online: https://assets.publishing.service.gov.uk/government/uploads/system/uploads/attachment_data/ file/575973/The_Casey_Review_Report.pdf (accessed on 1 December 2018).

Chemerinsky, Erwin. 2014. Freedom from Religion Foundation Convention Speech. October 25. Available online: https:/ /ffrf.org/news/video/item/22802-legal-titan-chemerinsky-champions-first-amendment (accessed on 15 December 2018).

Chugani, Sumeet H. 2008. Benevolent Blood Money: Terrorist Exploitation of Zakat and Its Complications in the War on Terror. North Carolina Journal of International Law and Commercial Regulation 34: 601-54.

CNN News. 2013. House Homeland Security Chairman Believes Suspect Trained in Russia. CNN News, April 21. Available online: http:/ / politicalticker.blogs.cnn.com/2013/04/21/house-homeland-security-chairmanbelieves-suspect-trained-in-russia/comment-page-1/ (accessed on 1 December 2018).

Cox, Daniel, E. J. Dionne Jr., Robert P. Jones, and William A. Galston. 2011. What It Means to Be American; Attitudes towards Increasing Diversity in America Ten Years after 9/11. Public Religion Research Institute, September 6. Available online: https://www.prri.org/research/what-it-means-to-be-american/ (accessed on 1 December 2018).

Daily Mail. 2012. Anti-bullying Speaker Dan Savage Blasts Christian Teens Who Walked out of Lecture after He Criticised 'Bullsht in the Bible'. Daily Mail, April 28. Available online: https:/ /www.dailymail.co.uk/news / article-2136502/Dan-Savage-blasts-Christian-teens-walked-lecture-criticised-bullsh-t-Bible.html (accessed on 1 December 2018).

De Maio, Gerald, and Louis Bolce. 2002. Our Secularist Democratic Party. The Public Interest 149: 2-30.

Department of Justice Memorandum. 2004. Abdurahman Alamoudi Sentenced to Jail in Terrorism Financing Case. October 15. Available online: https:/ / www.justice.gov/archive/opa/pr/2004/October/04_crm_698.htm (accessed on 1 December 2018).

Drake, Bruce. 2014. Public Strongly Backs Affirmative Action Programs on Campus. Pew Research Center, August 22. Available online: http:/ / www.pewresearch.org/fact-tank/2014/04/22/public-strongly-backsaffirmative-action-programs-on-campus/ (accessed on 10 December 2018).

Druzenko, Gennadiy. 2010. Religion and the Secular State in Ukraine. In Religion and the Secular State: National Reports. Edited by Javier Martinez-Torron and W. Cole Durham Jr. Washington, DC: International Center for Law and Religion Study.

Dworkin, Ronald. 2006. Is Democracy Possible Here. Princeton: Princeton University Press.

Eisgruber, Christopher. 2006. Secularization, Religiosity and the United States Constitution. Indiana Journal of Global Legal Studies 13: 445-72. [CrossRef]

Eisgruber, Chris, and Lawrence Sager. 2007. Religious Freedom and the Constitution. Cambridge: Harvard University Press. 
Erickson, Amanda. 2017. How the USSR's Effort to Destroy Islam Created a Generation of Radicals. The Washington Post, January 5.

Esbeck, Carl H. 2007. The 60th Anniversary of the Everson Decision and America's Church-State Proposition. Journal of Law and Religion 23: 15-41. [CrossRef]

Evans, Martin. 2017. Political Correctness is Allowing Islamic Terrorism to Flourish, Government Tsar Warns. The Telegraph, November 2. Available online: https:/ / www.telegraph.co.uk/news/2017/11/02/politicalcorrectness-allowing-islamic-terrorism-flourish-government/ (accessed on 10 December 2018).

Fallaci, Oriana. 2002. The Rage and the Pride. New York: Rizzoli.

Family Research Council. 2017. Hostility to Religion: The Growing Threat to Religious Liberty in the United States. Family Research Council. p. 3. Available online: https:// downloads.frc.org/EF/EF17F51.pdf (accessed on 15 December 2018).

Fea, John. 2011. Was America Founded as a Christian Nation? A Historical Introduction. Westminster: John Knox Press.

Federer, William J. 2008. Moderate Muslims Turning Radical? WorldNetDaily, February 15. Available online: https:/ / www.wnd.com/2008/02/56286/ (accessed on 1 December 2018).

Fisher, Martin. 2019. City Ordinance: Austin Churches Must Hire Homosexual, Transsexual Pastors. Christian Action Network, October 24. Available online: https:/ / christianaction.org/city-ordinance-austin-churchesmust-hire-homosexual-transexual-pastors / (accessed on 4 January 2019).

Fox News. 2015. Neighbor to Family of San Bernardino Terrorist Couple Purportedly Saw but Didn't Report 'Suspicious Activity'. Fox News, December 5. Available online: https:/ / www.foxnews.com/us/neighbor-tofamily-of-san-bernardino-terrorist-couple-purportedly-saw-but-didnt-report-suspicious-activity (accessed on 1 December 2018).

Fox News. 2017. Diversity Visa Program: What You Need to Know. Fox News, November 1. Available online: https: / / www.foxnews.com/politics/diversity-visa-program-what-you-need-to-know (accessed on 10 December 2018).

Gearon, Liam. 2013. The Counter Terrorist Classroom: Religion, Education, and Security. Religious Education 108: 129-47. [CrossRef]

Gearon, Liam, and Joseph Prud'homme. 2018. State Religious Education and the State of Religious Life. Eugene: Pickwick Publications.

George, Robert P., Charles J. Caput, William E. Lori, R. Albert Mohler Jr., and Russell Moore. 2015. Now is the Time to Talk about Religious Liberty. Public Discourse, April 3.

Gjelten, Tom. 2015. The Unintended Consequences of a 50-year-old U.S. Immigration Bill. Washington Post, September 25. Available online: https://www.washingtonpost.com/opinions/theunintended-consequences-of-a-50-year-old-us-immigration-bill/2015/09/25/8ba42cda-622f-11e58e9e-dce8a2a2a679_story.html?utm_term=.1422555e964d (accessed on 15 December 2018).

Goldman, Adam, and Eileen Sullivan. 2013. FBI Got Information from Russian FSB that Tamerlan Tsarnaev Was Radical Islam Follower. The Washington Post, April 23.

Goodenough, Patrick. 2018. 'A Church without Putin': Ukraine's Orthodox Christians Declare Independence from Moscow. cnsnews.com, December 17. Available online: https://www.cnsnews.com/news/article/patrickgoodenough/church-without-putin-ukraines-orthodox-christians-declare (accessed on 20 December 2018).

Goodlatte, Rep. Bob. 2017. Visa Lottery Program is too Much of a Gamble for our Nation and Needs to End. The Hill, November 6. Available online: https:/ / thehill.com/blogs/congress-blog/homeland-security /358970visa-lottery-program-is-too-much-of-a-gamble-for-our (accessed on 20 December 2018).

Goodman, Carly. 2017. The Visa Lottery Wins America Goodwill. Ending It It's a Mistake. The Washington Post, November 2. Available online: https:/ /www.washingtonpost.com/news/posteverything/wp/2017/11/ 02/the-visa-lottery-wins-america-goodwill-ending-it-is-a-mistake/?utm_term=.a4f6d0ea11b2 (accessed on 20 December 2018).

Green, Steven K. 2010. The Second Disestablishment: Church and State in Nineteenth-Century America. Oxford: Oxford University Press.

Hajjar, Sami G. 2002. Avoiding Holy War: Ensuring that the War on Terrorism is Not Perceived as a War on Islam. In Defeating Terrorism: Strategic Issue Analyses. Edited by John R. Martin. Carlisle: Strategic Studies Institute, U.S. Army War College.

Hamburger, Philip. 2002. Separation of Church and State. Cambridge: Harvard University Press.

Hamburger, Philip. 2004. Against Separation. National Affairs 177-92. 
Hannah, Daryl. 2014. Here's Why This LGBT Policy Shop Has Been a Magnet for Funding. Inside Philanthropy. Available online: https://www.insidephilanthropy.com/home/2014/9/11/heres-why-this-lgbt-policyshop-has-been-a-magnet-for-fundin.html (accessed on 1 December 2018).

Harnden, Tony. 2010. Barack Obama: NASA Must Try to Make Muslims 'Feel Good'. The Telegraph, July 6. Available online: https://www.telegraph.co.uk/news/science/space/7875584/Barack-Obama-Nasa-musttry-to-make-Muslims-feel-good.html (accessed on 10 December 2018).

Hing, Bill Ong. 2012. Defining America through Immigration Policy. Philadelphia: Temple University Press.

Hitchcock, James. 2004. The Supreme Court and Religion in American Life, Vol. II: From "Higher Law" to "Sectarian Scruples". Princeton: Princeton University Press.

Hosenball, Mark. 2013. Boston Bomb Suspect's Name Was on Classified Government Watch Lists. Reuters, April 24. Available online: https:/ / www.reuters.com/article/us-usa-explosions-boston-suspect/bostonbomb-suspects-name-was-on-classified-government-watch-lists-idUSBRE93N06720130424 (accessed on 1 December 2018).

Huizinga, Todd. 2016. The New Totalitarian Temptation: Global Governance and the Crisis of Democracy in Europe. New York: Basic Books.

Institute for Economics and Peace. 2015. Five Key Questions Answered on the Link between Peace and Religion. Institute for Economics and Peace. Available online: http:/ / economicsandpeace.org/wp-content/uploads / 2015/06/Peace-and-Religion-Report.pdf (accessed on 15 December 2018).

Jewish News Syndicate. 2018. New York City Schools to Provide Kosher Food as Part of New Pilot Program. Jewish News Syndicate, June 24. Available online: https:/ / www.jns.org/new-york-city-schools-to-provide-kosherfood-as-part-of-new-pilot-program/n (accessed on 29 December 2018).

Johnston, David, and Don van Natta Jr. 2002. Wary of Risk, Slow to Adapt, F.B.I. Stumbles in Terror War. The New York Times, June 2. Available online: https:/ /www.nytimes.com/2002/06/02/us/wary-of-risk-slow-toadapt-fbi-stumbles-in-terror-war.html (accessed on 1 December 2018).

Kephart, Janie. 2011. Amending the Immigration and Nationality Act to Eliminate the Diversity Lottery Immigrant Program. Testimony to the House Judiciary Subcommittee on Immigration Policy and Enforcement, April 5. Available online: https://cis.org/Testimony/Amending-Immigration-and-Nationality-Act-EliminateDiversity-Visa-Lottery-immigrant (accessed on 10 December 2018).

Kozioff, Nikolas. 2015. Ukraine: What's the Role of Religion in the Post-Maidan Milieu. March 26. Available online: https:/ / www.huffingtonpost.com/nikolas-kozloff/ukraine-whats-the-role-of_b_6950284.html (accessed on 20 December 2018).

Leiter, Brian. 2012. Why Tolerate Religion? Princeton: Princeton University Press.

Lietzau, William K. 1990. Rediscovering the Establishment Clause: Federalism and the Rollback of Incorporation. De Paul Law Review 39: 1191-234.

Lipka, Michael. 2015. Millennials Increasingly Are Driving Growth of 'Nones'. Pew Research Center, May 12. Available online: http://www.pewresearch.org/fact-tank/2015/05/12/millennials-increasingly-aredriving-growth-of-nones/ (accessed on 20 December 2018).

Lipka, Michael. 2016. 10 Facts about Atheists. Pew Research, June 1. Available online: http:/ /www.pewresearch. org/fact-tank/2016/06/01/10-facts-about-atheists (accessed on 1 December 2018).

Marcus, Lori Lowenthal. 2014. Muslims Want Halal Food in NYC Schools-Kosher Not an Option. The Jewish Press, March 27. Available online: http://www.jewishpress.com/news/breaking-news/muslims-wanthalal-food-in-nyc-schools-kosher-not-option/2014/03/27/ (accessed on 1 December 2018).

Mark, Michelle. 2017. Trump is Assailing the Diversity Lottery after the NYC Terror Attack—Her's What It Is. Business Insider. November 1. Available online: https:/ / www.businessinsider.com/what-is-diversity-visalottery-trump-eliminate-nyc-terror-attack-2017-11 (accessed on 15 November 2018).

Markind, Johanna. 2015a. Federal Government Subsidizes Halal Food in Public Schools. PJ Media, August 28. Available online: https:/ / pjmedia.com/blog/federal-government-subsidizes-halal-food-in-public-schools / 2/ (accessed on 15 November 2018).

Markind, Johanna. 2015b. Federal Government Subsidizes Halal Food in Public Schools. Middle East Forum, August 28. Available online: https:/ / www.meforum.org/articles/2015/federal-government-subsidizeshalal-food-in-public (accessed on 1 November 2018).

Marshall, William P. 1991. The Concept of Offensiveness in Establishment and Free Exercise Jurisprudence. Indiana Law Journal 66: 351-77. 
Marx, Karl, and Frederick Engels. 1848. Manifesto of the Communist Party. p. 16. Available online: https: / / www.marxists.org/archive/marx/works/download/pdf/Manifesto.pdf (accessed on 1 November 2018).

Maslow, Abraham Harold. 1943. A Theory of Human Motivation. Psychological Review 50: 370-96. [CrossRef]

May, Caroline. 2014. Obama Admin Unilaterally Changes Law to Allow Immigrants with 'Limited' Terror Contact into U.S. dailycaller.com, February 5. Available online: https:/ / www.dailycaller.com/2014/02/05/obamaadmin-changes-immigration-law-allows-immigrants-who-supported-terrorists-into-us / (accessed on 1 November 2018).

McCarthy, Andrew C. 2010. Grand Jihad. New York: Encounter.

McCarthy, Andrew C. 2016. Obama: Anti-Anti-Terrorist. National Review, June 18. Available online: https: / www.nationalreview.com/2016/06/obama-muslim-brotherhood-terrorism-radical-islamviolent-extremism/ (accessed on 3 November 2015).

McConnell, Michael W. 1990. The Origins and Historical Understanding of Free Exercise of Religion. Harvard Law Review 103: 1416-517. [CrossRef]

McKim, Robert. 2001. Religious Ambiguity and Religious Diversity. Oxford: Oxford University Press.

McKim, Robert. 2012. On Religious Diversity. New York: Oxford University Press.

McKinstry, Leo. 2007. How the Government Has Declared War on White English People. Daily Express, August 9.

Meckler, Laura. 2010. Obama Joins ‘It Gets Better' Campaign; Dan Savage Says: Make it Better. Wall Street Journal, October 22. Available online: https://blogs.wsj.com/washwire/2010/10/22/obama-joins-it-gets-bettercampaign-dan-savage-says-make-it-better/ (accessed on 15 December 2018).

Moravcsik, Andrew. 2008. The Myth of Europe's Democratic Deficit. Intereconomics: Journal of European Public Policy 43: 331-40.

Morrissey, Ed. 2018. Italy: FBI Helped U.S. Take Down ISIS Plot against Vatican. Hotair.com, December 17. Available online: https:/ /hotair.com/archives/2018/12/17/italy-fbi-helped-us-take-isis-plot-vatican/ (accessed on 29 December 2018).

Murray, Douglas. 2017. Strange Death of Europe: Immigration, Identity, Islam. London: Bloomsbury.

Murray, Douglas. 2018. UK Welcomes Extremists, Bans Critics of Extremists. Gatestone Institute, December 29. Available online: https://www.gatestoneinstitute.org/13455/britain-extremists (accessed on 3 January 2019).

National Institute on Drug Abuse. 2016. What are Hallucinogens? January. Available online: https://www. drugabuse.gov/publications/drugfacts/hallucinogens (accessed on 11 December 2018).

NBC News. 2006. Is the FBI Doing Its Best to Combat Terrorism. NBC News. Available online: http:/ /www.nbcnews.com/id/16042604/ns/nbc_nightly_news_with_brian_williams-nbc_news_ investigates/t/fbi-doing-its-best-combat-terrorism/\#.XC9hdlxKg2w (accessed on 12 December 2018).

Nehamas, Alexander. 1987. Nietzsche: Life as Literature. Cambridge: Harvard University Press.

Ngai, Mae. 2004. Impossible Subjects: Illegal Aliens and the Making of Modern America. Princeton: Princeton University Press.

Norris, Pippa, and Ronald Inglehart. 2004. Sacred and Secular: Religion and Politics Worldwide. New York: Cambridge University Press.

Nussbaum, Martha. 2008. Contemporary Controversies: The Pledge, Evolution, Imagination, Gay Marriage, Fear of Muslims. In Liberty of Conscience: In Defense of America's Tradition of Religious Freedom. New York: Basic Books.

Oprea, Megan G. 2016. Americans Will Accept Islam Once the Left Stops Giving It Special Privileges. The Federalist, November 17. Available online: http:/ / thefederalist.com/2016/11/17/americans-will-accept-islam-oncethe-left-stops-giving-it-special-privileges / (accessed on 19 November 2018).

Pew Forum. 2017. American Express Increasingly Warm Feelings toward Religious Groups. Pew Forum, February 15. Available online: http:/ / www.pewforum.org/2017/02/15/americans-express-increasingly-warm-feelingstoward-religious-groups / (accessed on 15 November 2018).

Pew Research Center. 2013. Religious Affiliation of U.S. Immigrants: Majority Christian, Rising Share of Other Faiths. May 17. Available online: http:/ / www.pewforum.org/2013/05/17/the-religious-affiliation-of-usimmigrants / (accessed on 28 December 2018).

Pew Research Center. 2017a. Religious Belief and National Belonging in Central and Eastern Europe. May 10. Available online: http:/ /www.pewforum.org/2017/05/10/religious-belief-and-national-belonging-incentral-and-eastern-europe/ (accessed on 28 December 2018). 
Pew Research Center. 2017b. The Partisan Divide on Political Values Grows even Wider. October 5. Available online: http:/ / assets.pewresearch.org/wp-content/uploads/sites/5/2017/10/05162647/10-052017-Political-landscape-release.pdf (accessed on 10 December 2018).

Pew Research Center. 2017c. Attitudes toward Increasing Diversity in the U.S. February 16. Available online: http:/ / www.people-press.org/2017/02/16/4-attitudes-toward-increasing-diversity-in-the-u-s/ (accessed on 10 December 2018).

Pipes, Daniel. 2005. Which Privileges for Islam. New York Sun, March 15. Available online: https://www. danielpipes.org/2468/which-privileges-for-islam (accessed on 10 December 2018).

Pipes, Daniel. 2006. More Special Privileges for Muslims. Available online: https:/ /www.danielpipes.org/2468/ which-privileges-for-islam and http:/ / www.danielpipes.org/blog/2006/07/more-special-privileges-formuslims (accessed on 15 December 2018).

Preston, Caroline. 2010. Muslim Groups Urge Obama to Ease Giving Restrictions. The Chronicle of Philanthropy, March 24. Available online: https://www.philanthropy.com/article/Muslim-Groups-Urge-Obama-to/ 161065 (accessed on 15 December 2018).

Qutb, Sayyid. 2000. Social Justice in Islam. North Haledon: Islamic Publications International.

Rafizadeh, Majid. 2017. Stop the 'Diversity' Visa Lottery, Gateway for Jihadists. Gatestone Institute, November 2. Available online: https://www.gatestoneinstitute.org/11273/diversity-visa-lottery (accessed on 10 December 2018).

Ross, Brian, Rhonda Schwartz, James Gordon Meek, and Josh Margolin. 2015. Secret U.S. Policy Blocks Agents from Looking at Social Media of Visa Applicants, Official Says. ABC News, December 14. Available online: https: / / abcnews.go.com/US/secret-us-policy-blocks-agents-social-media-visa/story?id=35749325 (accessed on 20 December 2018).

Savage, Dan. 2012. On "Bullshit" and "Pansy-Assed". The Stranger, April 29. Available online: http://slog. thestranger.com/slog/archives/2012/04/29/on-bullshit-and-pansy-assed (accessed on 2 January 2019).

Scott, Eugene. 2017. Trump's Latest Target, the Diversity Visa Program, Wasn't Always Aimed at Achieving Diversity. The Washington Post, November 3. Available online: https://www.washingtonpost.com/ news/the-fix/wp/2017/11/03/trumps-latest-target-the-diversity-visa-program-wasnt-always-aimed-atachieving-diversity /?utm_term=.3ee4f03bcf93 (accessed on 20 December 2018).

Sehat, David. 2016. The Myth of American Religious Freedom, updated ed. New York: Oxford University Press.

Shapiro, Ben. 2012. Obama White House Fundraises for Anti-Christian Bully Savage. Breitbart News, April 29. Available online: https:/ /www.breitbart.com/politics/2012/04/29/obama-administration-dan-savage/ (accessed on 1 December 2018).

Slodysko, Brian. 2018. Emails: Conservatives Slammed then-Gov. Mike Pence in 2015 for Changing Religious Freedom Law. Associated Press, March 28. Available online: https://www.indystar.com/story/news/ politics /2018/03/28/emails-conservatives-slammed-then-gov-mike-pence-2015-changing-religiousfreedom-law/467254002/ (accessed on 20 December 2018).

Smith, Gregory A., and Alan Cooperman. 2016. The Factors Driving Growth of Religious 'Nones' in the U.S. Pew Research Center, September 14. Available online: http:/ / www.pewresearch.org/fact-tank/2016/09/14/thefactors-driving-the-growth-of-religious-nones-in-the-u-s/ (accessed on 20 December 2018).

Sperry, Paul. 2008. Infiltration: How Muslim Spies and Subversives Have Penetrated Washington. Nashville: Thomas Nelson.

Steinberg, Guido. 2013. German Jihad: On the Internationalization of Islamist Terrorism. New York: Columbia University Press.

Sullivan, Winnifred Fallers. 2005. The Impossibility of Religious Freedom. Princeton: Princeton University Press.

Sweetman, Brendan. 2006. Why Politics Needs Religion: The Place of Religious Arguments in the Public Square. Downers Grove: InterVarsity Press.

Sweetman, Brendan. 2010. Secularism and Religion in Modern Democracies. E-International Relations, August 4. Available online: https: / /www.e-ir.info/2010/08/04/secularism-and-religion-in-modern-democracies / (accessed on 28 December 2018).

The Christian Century. 1999. Disestablishment for the Church of Sweden. The Christian Century, June 16, p. 116, No. 18. Available online: https://www.questia.com/read/1G1-55056921/disestablishment-for-church-ofsweden (accessed on 1 November 2018). 
The Qualifications and Curriculum Authority. 2010. Religious Education in English Schools. London: Department for Children, Schools and Families.

The White House. 2009. The President's speech in Cairo: A new beginning. President Obama, June 4. Available online: https:/ / obamawhitehouse.archives.gov/issues/foreign-policy/presidents-speech-cairo-a-newbeginning (accessed on 15 November 2018).

The White House. 2012. Remarks by the President to the UN General Assembly. The White House. Available online: https:/ / obamawhitehouse.archives.gov/the-press-office/2012/09/25/remarks-presidentun-general-assembly (accessed on 15 November 2018).

Tilly, Charles. 1994. States and Nationalism in Europe, 1492-1992. Theory and Society 23: 131-46. [CrossRef]

Toynbee, Polly. 2010. Goodbye to the Bishops. The Guardian, March 14.

Trigg, Roger. 2008. Religion in Public Life: Must Faith Be Privatized? Oxford: Oxford University Press.

Trigg, Roger. 2013a. Equality, Freedom, and Religion. Oxford: Oxford University Press.

Trigg, Roger. 2013b. Threats to Religious Freedom in Europe. Public Discourse, June 28. Available online: https: / / www.thepublicdiscourse.com/2013/06/10439/ (accessed on 1 November 2018).

Trigg, Roger. 2014. Religious Diversity: Philosophical and Political Dimensions. Cambridge: Cambridge University Press.

Twenge, Jean M., Ryne A. Sherman, Julie J. Exline, and Joshua B. Grubbs. 2016. Declines in American Adults' Religious Participation and Beliefs, 1972-2014. Sage Open 6: 2. [CrossRef]

Vesnic-Alujevic, Lucia, and Rodrigo Castro Nacarino. 2012. The E.U. and its Democratic Deficit: Problems and (Possible) Solutions. European View 11: 63-70. [CrossRef]

Walker, Graham. 2000. Illusory Pluralism, Inexorable Establishment. In Obligations of Citizenship and Demands of Faith: Religious Accommodation in Pluralist Democracies. Edited by Nancy Rosenblum. Princeton: Princeton University Press.

Warth, Gary. 2017. San Diego Unified to Fight Islamophobia, Bullying. The San Diego Union-Tribune, April 5. Available online: https://www.sandiegouniontribune.com/news/education/sd-me-islam-unified20170405-story.html (accessed on 15 November 2018).

The William H. Webster Commission. 2012. The Final Report of the William Webster Commission on the Federal Bureau of Investigation, Counterterrorism Intelligence, and the Events at Fort Hood, Texas on November 5, 2009. Released in Redacted Form. July 19. Available online: https:/ /www.hsdl.org/ ?abstract\&did=717443 (accessed on 26 December 2018).

Wenger, Tisa. 2013. American Religious Freedom: Pride and Prejudice. Reflections: A Magazine of Theological and Ethical Inquiry from Yale Divinity School. Available online: https:/ / reflections.yale.edu/article/future-race/ american-religious-freedom-pride-and-prejudice (accessed on 1 November 2018).

Wenger, Tisa. 2017. Religious Freedom: The Contested History of an American Ideal. Chapel Hill: University of North Carolina Press.

West, Thomas G. 2001. Vindicating the Founders: Race, Sex, Class, and Justice in the Origins of America. Lanham: Rowman and Littlefield.

Wilken, Robert Louis. 2004. The Church as Culture. First Things. Available online: https:/ /www.firstthings.com/ article/2004/04/the-church-as-culture (accessed on 15 November 2018).

Williams, Walter L. 1992. The Spirit and the Flesh: Sexual Diversity in American Indian Culture. Boston: Beacon Press. Wolf, Jonathan. 2011. Ethics and Public Policy: A Philosophical Inquiry. London: Routledge.

Woolf, Linda M. 2017. Codifying Discrimination: Trump's Anti-transgender Policy. Psychology Today, July 26. Available online: https:/ / www.psychologytoday.com/us/blog/the-fight-against-hate/201707/codifyingdiscrimination-trump-s-anti-transgender-policy (accessed on 1 December 2018).

Zimmerman, Jonathan. 2012. Anti-Blasphemy Laws Have a History in America. Newsworks, October 9. Available online: http:/ / www.newsworks.org/index.php/local/thats-history / 45356anti-blasphemy-laws-have-ahistory-in-america (accessed on 1 November 2018).

(C) 2019 by the author. Licensee MDPI, Basel, Switzerland. This article is an open access article distributed under the terms and conditions of the Creative Commons Attribution (CC BY) license (http:/ / creativecommons.org/licenses/by/4.0/). 